\title{
İstanbul Ermeni Patrikliği'nin Osmanlı Hükümeti’yle Münasebetlerine Tesir Eden Dinamikler (18. Yüzyılın İlk Yarısı)*
}

The Dynamics Affecting the Relations of Armenian Patriarchate with the Ottoman Government (The First Half of the 18th Century)

Ensar KÖSE

Türkçe ve Sosyal Bilimler Eğitimi Bölümü, İstanbul Üniversitesi, İstanbul, Türkiye

\begin{abstract}
Özet
Bu çalışmada, 18. yüzyılın ilk yarısında İstanbul Ermeni Patrikliği'nin Osmanlı Hükümeti'yle olan münasebetlerinin ana çerçevesi ele alınmıştır. Araştırmanın asıl kaynakları, Başbakanlık Osmanlı Arşivi'ndeki belge ve defterlerden oluşmaktadır. Bunlar arasında özellikle İstanbul'daki patriklerin, çeşitli meselelerde hükümete sundukları arzuhâllerin önemli bir yeri vardır. Zira bu belgeler, muhtevanın yanı sıra, iki taraf arasındaki bürokratik mekanizmanın işleyişi hakkında da kıymetli bilgiler verir. Nitekim çalışmada, öncelikle belgelerin şekil özelliklerinden hareketle, münasebetlerin görünürdeki işleyişine bakılmıştır. Daha sonra yazışmaların muhtevaları incelenerek, patriklik makamının hükümetle olan münasebetlerine tesir eden başlıca dinamiklerin (marhasa tayinleri, malî meseleler, Kudüs Patrikliği ile münasebetler, cemaat içindeki yozlaşma vb.) neler olduğu gösterilmeye çalışılmıştır.

Anahtar Kelimeler: Osmanlı Devleti, 18. Yüzyıl, İstanbul Ermeni Patrikliği, Ermeni Cemaati.
\end{abstract}

\begin{abstract}
In this study, the main framework of the relationship of Istanbul Armenian Patriarchate with the Ottoman Government in the first half of the 18th century has been discussed. The original sources of the study consist of the documents and records in the Prime Ministry Ottoman Archives. Especially among these sources, the petitions (arzuhâls) about various issues which were submitted to the Government by Armenian Patriarchs are very important. They provide valuable information about the bureaucratic process between the two sides. Thus, in this study, firstly, based on the formal properties of the documents, the visible action of the relationship has been reviewed. Later, by viewing the content of the records, it has been tried to be understood what the main dynamics are (such as the appointment of marhasa, fiscal issues, the relation with Jerusalem Patriarchate, corruption among the community etc.) that affected the relationship of the Patriarchate with the Ottoman Government.

Key Words: Ottoman State, $18^{\text {th }}$ Century, Istanbul Armenian Patriarchate, Armenian Community
\end{abstract}

CONTACT : Ensar KÖSE, ensarkose@gmail.com

Geliş Tarihi \& First Received : 28.03.2017

Kabul Tarihi \& Accepted : : 16.04.2017

* Bu makale, 8-11 Nisan 2015 tarihinde Akdeniz Üniversitesi tarafından düzenlenen "Kadim Dostluğun Yüz Y1llık Açmazında Türk-Ermeni İlişkileri Uluslararası Sempozyumu: Toplumsal Bellek, Önyargılar ve Gerçekler” başlıklı sempozyumda sözlü sunulmuş olan bildirinin, gözden geçirilmiş ve genişletilmiş halidir. 


\section{Giriş}

Osmanlı Devleti'nde Ermeniler, diğer başka azınlıklar gibi, "millet sistemi”nin çizdiği sınırlar içerisinde yaşıyorlard1. ${ }^{1}$ Siyasî otorite nezdindeki hak ve sorumlulukları, kendilerine verilen resmî belgelerde açılanmış ve uzun yıllardır süregelen uygulamalarla oturmuş bir düzene kavuşmuştu. Umumî bir prensip olarak, cemaatin iç yapısını ilgilendiren hususlara devlet tarafından müdahale edilmiyordu. Ruhbanın göreve tayini, azli, terfi ve tecziyeleri tamamen İstanbul'daki Ermeni Patrikhanesi'nin yetkisindeydi. Cemaat mensuplarının ödemeleri gereken vergilerin tahsili gibi malî yükümlülükler de patrik marifetiyle takip edilirdi. Arşiv belgelerine bakılırsa, Osmanlı Hükümeti ile Ermeni Patrikhanesi arasında, iktisadî yönü ağır basan münasebetlerin olduğu görülür. Bu yüzden cemaatin hükümet nezdindeki resmî işleri, Bâb-1 Defteri’ye bağlı bir büro olarak teşkilatlandırılan Piskoposluk Kalemi vasıtasıyla yürütülüyordu.

18. yüzyıla girilirken, Osmanlı Devleti'nin azınlık cemaatlerine yönelik politikasını değiştirecek yeni bir durum mevcut değildi. Gerçi batıdaki uzun savaşların Osmanlı malî sistemi üzerindeki yıpratıcı etkisi, vergi artışları ve taşrada merkezî otoriteyi sarsacak boyutta birtakım güvenlik zafiyeti şeklinde tezahür ederek, müslim ve gayrimüslim tüm ahaliyi zorda bırakmıştı. ${ }^{2}$ Ama herhalde savaş yıllarının zorlu koşulları, diğer azınlıklar gibi askerlik yükümlülüğünden muaf olan Ermeni cemaatini de, nispeten daha az etkilemiş olmalıdır. Bu araştırmanın zaman sınırını belirleyen 18. asrın ilk yarısı boyunca, savaşların sürdüğü dönemlerde de, İstanbul Ermeni Patrikliği'nin ödediği mirî pişkeş ve maktû vergilerin miktarında herhangi bir artışın olmaması; ayrıca gözden geçirilen arşiv kayıtlarında, vergi ödeme hususunda yakınmalara nadiren rastlanması, cemaat mensuplarının savaş şartlarından dramatik boyutta etkilenmemiş olduklarına işaret etmelidir.

Şu halde Ermeni cemaati ve bunların Osmanlı Devleti nezdindeki en üst teşekkülü olan İstanbul Patrikliği'nin, hükümetle münasebetlerine tesir eden dinamiklerin neler olabileceğine bakmak gerekir. Nitekim bu çalışma, esas itibariyle söz konusu amaca mâtuf olarak sistematik taramayla elde edilen arşiv belgelerinin sağladığı verilerle temellendirilmiştir. Başbakanlık Osmanlı Arşivi'nde mevcut olan Piskoposluk Kalemi kayıtlarını muhtevî defterler, dosyalar ve müteferrik vesikalar taranmıştır. Elde edilen belgeler içinden, münhasıran İstanbul Ermeni patriklerinin Divân-1 Hümâyun'a sundukları arzuhâllere odaklanılmıştır. Zira cevabı aranan asıl soru, Patrikhane'nin Osmanlı Hükümeti'yle münasebetine yön veren etkenlerin neler olabileceği hususudur. $\mathrm{Bu}$ konuda objektif cevabı sağlayacak belgelerin, söz konusu arzlar olduğu düşünülmüştür. Patrik M1khitar'ın görevde olduğu 1699'dan başlayarak, Patrik IX. Hovhannes'in 26 yıllık uzun görev süresini sonlandıran 1741'deki ölümünde kadar geçen, takribi yarım asırlık süreye ait toplam 242 adet patrik arzuhâli görülmüştür. Belgeler, şekil ve muhteva yönünden incelenmek suretiyle bazı istatistikî veriler elde edilmiştir. Bu verilerden hareketle, söz konusu dönemde Ermeni cemaatinin karşı karşıya bulunduğu temel meselelerin neler olduğu ve cemaatin, Osmanlı Hükümeti'yle münasebetlerine tesiri tebarüz ettirilmeye çalıș1lacaktır. Mesele iki alt başlıkta ele alınacaktır. Öncelikle Ermeni Patrikhanesi’nin Osmanlı Hükümeti’yle kurduğu

\footnotetext{
${ }^{1}$ Osmanlı Devleti'ndeki azınlıkların durumu ve genel olarak "millet sistemi” hakkında tafsilatlı malumat için şu çalışmalara bakılabilir: M. Macit Kenanoğlu, Osmanlı Millet Sistemi, Mit ve Gerçek, Klasik Yayınları, İstanbul 2004, s. 47-51; Benjamin Braude, "Foundation Myths of the Millet System", Christians and Jews in the Ottoman Empire, the Functioning of a Plural Society, ed. B. Braude \& B. Lewis, I, New York 1982, s. 69-88; Yavuz Ercan, "Osmanl Devleti'nde Müslüman Olmayan Topluluklar (Millet Sistemi)”, Osmanl, Cilt: 4, Yeni Türkiye Yayınları, Ankara 1999, s. 197-207; Cevdet Küçük, “Osmanlı Devleti'nde Millet Sistemi”, Osmanlı, Cilt: 4, Ankara 1999, s. 208-216; Yuluğ Tekin Kurat, "Çok Milletli Bir Ulus Olarak Osmanlı İmparatorluğu”, Osmanl, Cilt: 4, Ankara 1999, s. 217-222; Benjamin Braude, "Millet Sisteminin İlginç Tarihi”, Osmanlı, Cilt: 4, Ankara 1999, s. 245-254; Nuri Adıyeke, "Islahat Fermanı Öncesinde Osmanlı İmparatorluğu'nda Millet Sistemi ve Gayrimüslimlerin Yaşantılarına Dair”, Osmanll, Cilt: 4, Ankara 1999, s. 255-261.

${ }^{2}$ Ermeni meselesine dair Erciyes Üniversitesi tarafindan düzenlenen bir sempozyumun açılış oturumunda Yusuf Halaçoğlu, II. Viyana Kuşatması sonrasındaki uzun savaş yıllarının, ağır vergiler ve idaredeki aksaklıklar sebebiyle Müslüman olsun veya olmasın bütün halk kesimi üzerinde ciddi etkileri olduğuna vurgu yapmıştır (Hoşgörü Toplumunda Ermeniler, Cilt: 1, Erciyes Üniversitesi Yayınları, Kayseri 2007, s. V).
} 
münasebetlerin, resmî statü ve yetki sınırları bakımından nasıl göründüğüne bakılacak; bu meyanda patrik atamaları ve bürokratik işleyiş gözden geçirilecektir. İkinci ve asıl bölümde ise, patrik arzlarından hareketle ilişkilere tesir eden dinamiklerin neler olduğu ortaya konulacaktır.

\section{Münasebetlerin Hukukî Yapısı ve Bürokratik İşleyişi}

Ermeni cemaatinin Eçmiyadzin, Kudüs ve Ahtamar gibi önemli dinî merkezleriyle kıyaslandığında, İstanbul Patrikliği’nin tarihinin çok da eskilere gitmediği görülür. Zira burası, İstanbul'un fethinden sonra Fatih Sultan Mehmed tarafından patriklik statüsünde kurulmuştur. ${ }^{3}$ Oysa Ermeni ruhanî hiyerarşisinin en üst teşekkülü katogigosluk idi. Buna rağmen İstanbul Ermeni Patrikliği'nin, hukukî yapısıyla mütenasip olmayan fiilî yetki kullanması, zamanla tarihçiler arasında bu kurumun statüsü hakkında tartışmaya sebep olmuştur. Örneğin Benjamin Braude, İstanbul Ermeni Patrikliği'nin aslında fiilî (de facto) yetki kullanan mahallî bir râhiblik konumunda olduğunu, asıl hukukî (de jure) yetkilerin ise Eçmiyadzin'deki baş-patrikte bulunduğunu iddia etmiştir. ${ }^{4}$ İstanbul Patrikliği’nin yetki alanının sınırları hususundaki görüşleriyle tartışmaya katılan Kevork Bardakcıyan ise, patriğin idaresinin sadece İstanbul ve ona bağlı yerlerde câri olduğunu söylemiştir. ${ }^{5} \mathrm{Bu}$ görüşlere karşı çıkan Macit Kenanoğlu, İstanbul Patrikliği'nin statüsünü belirleyen asıl hususun, Ermeni cemaati tarafından tanınıp tanınmadığı değil de, Osmanlı Devleti nezdinde ne şekilde kabul gördüğü keyfiyeti olduğuna dikkati çekmiştir. Yazar, bu yönüyle kilise kabul etmese de İstanbul Ermeni Patrikhanesi'nin varlığının, Osmanlı Devleti açısından de facto değil de jure olduğu görüşündedir. Kenanoğlu, yetki ve nüfuz alanı hususunda da Bardakcıyan'dan farklı düşünmekte, İstanbul Ermeni Patrikliği'nin daha başlangıçtan itibaren, diğer taşra patrikliklerinin yetki alanı dışında kalan tüm bölgelerde hâkim olduğunu yazmaktadır. ${ }^{6}$

Resmî belgelere bakıldığında, aslında diğer birçok hadisede olduğu gibi burada da Osmanlı idarecilerinin meseleye pragmatik şekilde yaklaştıkları görülür. Onların dikkat ettiği asıl husus, vergi tahsilinde aksama olmaması ve cemaatin kendi iç nizamını bozucu mahiyette adaletsizliklere firsat verilmemesi keyfiyetiydi. İdarenin bu hassasiyetlerini icrada İstanbul Patriği, Ermeni cemaatinin devletle münasebetlerindeki en önemli aktör olarak kabul edilmiştir. Patrikhane'nin fiilî statüsü, Ermeni cemaati açısından da böyledir. Zira İstanbul Patriği, sadece başkente yakın yerlerdeki Ermenilerin değil, aynı zamanda geniş imparatorluk sınırlarındaki bütün cemaat mensuplarının, devletle alakalı meselelerinde aracılık vazifesini yerine getiriyordu. Ayrıca tüm kilise ve manastırlara ruhban tayini veya görevden azli, patriğin arzı ve Sarayın onayıyla gerçekleşiyordu. Cemaat mensuplarının vergileri de yine patrik vasıtasıyla tahsil ediliyordu. Bu ve benzeri sebeplerle İstanbul Ermeni patriklerinin şahsiyetleri, Patrikhane'nin hükümetle olan münasebetlerinin seyrini müspet veya menfî yönde doğrudan etkilemiştir.

Patrik seçiminde oturmuş bir kural yoktu. Cemaatin iç dengelerinin yanı sıra, patrik namzetlerinin şahsî güç ve nüfuzları belirleyici oluyordu. Yaygın prosedüre göre patrik, Ermeni cemaatinin ruhanî ve sivillerinden oluşan bir konsey tarafından seçilir; ardından Saraydan onay alındıktan sonra kendisine yetki ve sorumluluklarını bildiren berat verilirdi. ${ }^{7}$ Mamafih bazen bu kurala riayet edilmediğini gösteren vak'alar da vardır. I. Avedik'in, 1702'de patrik tayin edilmesi hususunda Divân-1 Hümâyun'a sunduğu arzuhâl, bunun dikkat çekici bir örneğidir. Burada herhangi bir ayrıntı verilmeden, daha önce görev yaptığı Erzurum'da Frenk dinine karşı mücadelesinden bahsedilip, aynı mücadeleyi İstanbul'da vermesi için "şimdi Ermeniyân tâifesi

\footnotetext{
${ }^{3}$ İstanbul Ermeni Patrikhanesi'nin tarihi hakkında genel olarak şu eserlere bakılabilir: Davut Kılıç, Tarihten Günümüze İstanbul Ermeni Patrikhanesi, Atatürk Kültür Dil ve Tarih Yüksek Kurumu Yayınları, Ankara 2008; Canan Seyfeli, İstanbul Ermeni Patrikliği, Aziz Andaç Yayınları, Ankara 2005.

${ }^{4}$ Benjamin Braude, "Foundation Myths of the Millet System", s. 82.

${ }^{5}$ Kevork B. Bardakjian, "The Rise of the Armenian Patriarchate of Constantinople", Christians and Jews in the Ottoman Empire, the Functioning of a Plural Society, ed. B. Braude \& B. Lewis, I, New York 1982, s. 89-95. (Değerlendirmesi için bk: M. Macit Kenanoğlu, Osmanlı Millet Sistemi, s. 40-42).

${ }^{6}$ Bu tartışmaların tafsilatı için bakılabilir: M. Macit Kenanoğlu, Osmanlı Millet Sistemi, s. 47-51.

${ }^{7}$ Canan Seyfeli, İstanbul Ermeni Patrikliği, s. 84.
} 
bizi isterler" demekle yetinilmişti. ${ }^{8}$ Patrik seçimlerine Osmanlı Hükümeti'nin doğrudan müdahil olduğuna dair resmî belgelerde herhangi bir ipucuna rastlanmaz. Her ne kadar yeni patrik tayinlerinde pişkeş alınması hazineye gelir sağlasa da, cemaatin idaresinde apaçık istikrarsızlık anlamına gelecek şekilde s1k patrik değişikliğinden, devlet yöneticilerinin memnun olduğunu söylemek güçtür. Aksine bu istikrarsız durumun, sadece Ermeni cemaati için değil, aynı zamanda devlet için de vergi tahsilinde karışıklık ve aksama gibi bazı sıkıntılara sebep olduğu belgelerle sabittir. ${ }^{9}$

İstanbul Ermeni Patriği seçilen kişiler, göreve getirildiklerine dair kendilerine verilecek berat-l şerif mukabili, hazineye nakit olarak 100.000 akçe pişkeş (âdet-i pişkeş) ödeme yaparlardı. Ayrıca Anadolu ve Rumeli'de bulunan tüm Ermeni cemaatinin vergilerinin tahsili işi, Piskoposluk Mukataası tarafından İstanbul Patriği'ne senelik 140.000 akçe karşılığında maktû olarak ihale edilirdi. ${ }^{10}$ Kudüs Ermeni Patrikliği'ne bağlı cemaatin vergileri ise, 11.900 akçe makt $\hat{u}$ vergi ile ayrıca Kudüs Patriği'nin uhdesinde idi. İstanbul Patriği'ne, cemaat mensuplarından kanunla belirlenmiş vergileri tahsil edebilmek için, her y1l dört adet ferman verilirdi. Patrik Mıkhitar'ın, Mart 1700'de mutat şekilde söz konusu fermanların verilmesini talep eden arzında, bu dört fermanın Kayseri Mukataası fermanı, Kefe Mukataası fermanı, Rumeli fermanı ve İznikmid perâkendesi fermanı olduğu ifade edilmiştir. ${ }^{11}$

İstanbul Ermeni Patriği, Osmanlı Devleti'yle resmî münasebetlerini Divân-1 Hümâyun'a sunduğu arz/arzuhâl vasıtasıyla yürütürdü. Tipik bir patrik arzı, aşağıdaki örnekte gösterildiği şekilde olurdu:

"Devletlü ve sa 'âdetlü Sultânım hazretleri sağ olsun,

Bu râhib kulları hâlâ İstanbul ve tevâbi 'i Ermeni Patriği olup bi'l-fi'l patrikliğime dâhil Diyârbekir marhasası olan Sahak nâm râhib mürd olup marhasalı̆̆ mahlûl ve hâlî kalmă̆la yerine mahal ü müstahak olan Daniel nâm râhib her vechile lâyı ve Ermeni âyinleri icrâya kādir olmağla merhametlü Sultânımdan mercûdur ki, âdet-i pişkeşi teslîm-i hazîne edüp mezbûr Daniel'in yedine berât-ı âlî-şân sadaka ve ihsân olunmak bâbında emr ü fermân devletlü ve sa'âdetlü Sultânım hazretlerinindir.

\section{Bende Hovhannes, Patrik-i İstanbul, hâliyâ. "12}

Burada görüleceği üzere patrik arzları, marhasa azil ve tayinleri hakkında olabileceği gibi, ruhban ve cemaati ilgilendiren diğer başka hususlarda olması da mümkündü. Ruhbandan birinin cezalandırılmas $1^{13}$ veya affi ${ }^{14}$ talebi, kilise ve manastırlara müdahale, ${ }^{15}$ nikâh meselesine ait sorunlar, ${ }^{16}$ ruhban sınıfının yozlaşmas $1,{ }^{17}$ Eçmiyadzin Katogigosluğ ${ }^{18}$ ve Kudüs Patrikliği’ne ${ }^{19}$

\footnotetext{
${ }^{8}$ Başbakanlık Osmanlı Arşivi (BOA), Bâb-ı Defteri Piskoposluk Kalemi (D.PSK), Dosya nr: 2, Gömlek nr: 48 (7 Mart 1702).

${ }^{9}$ Patrik I. Avedik ile sâbık Patrik Yeprem arasında, vergi tahsili ve hazineye ödenmesi hususundaki ihtilaflar: BOA, D.PSK, 2/85, 87 (1702)

${ }^{10}$ BOA, D.PSK, $2 / 48$.

${ }^{11}$ BOA, D.PSK, $1 / 184$

12 Patrik Genceli VIII. Hovhannes'in arzuhâli, üzerinde pişkeşe ait derkenar kaydı ve 15 Cemâziyelâhir 1126 (28 Haziran 1714) tarihli buyuruldu: BOA, D.PSK, 5/12.

${ }^{13}$ Papas Haçadur'un Malkara'ya sürgünü hakkında Patrik Mıkhitar'ın arzı: BOA, D.PSK, 1/186 (1700).

${ }^{14}$ Limni adasına sürgün edilen Râhib Minas'ın affedilmesi hakkında Patrik IX. Hovhannes'in arzı: BOA, İbnülemin Dahiliye, nr. 2462 (1720)

${ }^{15}$ Erzincan Surp Hagop Manastırı Vakfına müdahalenin men'i hakkında Patrik I. Avedik'in arzı: BOA, D.PSK, 2/53 (1702).

16 Âyinlerine muhalif şekilde nikâh kıyılmasının men'i hakkında Patrik III. Mardiros’un arzı: BOA, D.PSK, 3/150 (1706).

${ }^{17}$ Bazı karabaşların görev yerlerine gitmediklerine dair Patrik I. Sahak'ın arzı: BOA, Kamil Kepeci (KK), nr. 2542-2, s. 53 (1711).

18 İstanbul'dan Eçmiyadzin'e ziyarete giden ruhban hakkında Patrik IX. Hovhannes'in arzı: BOA, KK, nr. 2542-8, s. 20b (1729).

${ }^{19}$ Kudüs'teki cemaat için sadaka toplaması hususunda Patrik IX. Hovhannes'in arzı: BOA, D.PSK, 5/88 (1716).
} 
dair meseleler, Frenklik (Latinlik) ile alakalı sorunlar, ${ }^{20}$ ehl-i örf ve diğer başka taraflardan cemaate yönelik baskılar, ${ }^{21}$ vergi tahsiline dair işler ${ }^{22}$ başta gelen yazışma konularındandı.

Bununla birlikte hükümete arzuhâl sunma hakkı, münhasıran patriklere ait değildi. Ruhban ve cemaat mensuplarının şahsî veya içtimaî konularda, İstanbul Patriği’nin aracıllğı olmaksızın, doğrudan doğruya Divân-1 Hümâyun'a müracaat ettikleri de görülürdü. Bu hususta birkaç örnek olarak şunlara bakılabilir: İstanbul'daki Ermeni cemaatinin, Samatya Sulu Manastır'ın tamiri hususunda Eylül 1702'deki müşterek arzuhâlleri; ${ }^{23}$ Sis Marhasası Râhib Matteos'un, bazı malî konulara dair Nisan 1704 tarihli arzuhâli; ${ }^{24}$ Ermeni cemaat-başıları, papasları ve sair ihtiyarlarının, İstanbul ve Kudüs patriklikleri hakkında Aralık 1721 tarihli müşterek arzuhâlleri. ${ }^{25}$

Ermeni Kilisesi'ne mensup ruhbandan Osmanlı Hükümeti'ne sunulan her tür müracaat, ayrım yapılmaksızın Osmanlı merkez bürokrasisinin işleyişine uygun şekilde muamele görürdü. Azil ve tayinle ilgili olanlar için, söz konusu marhasalık bölgesinin mîrî pişkeş ve mevcut idarî durumuna ait kayıtlar muhakkak çıkarılarak, arzuhâl kâğıdının üzerine derkenar olarak yazılırdı. Kesin kural olmamakla birlikte bazı müracaatlarda, en son onay mercii olan Sadrazama ve Padişaha sunulmadan önce meseleyi özetleyen telhis çıkarılırdı. Daha sonra müracaat hakkındaki nihai kararı gösteren buyuruldu sâdır olarak ilgili kaleme gönderilir; oradan da meselenin muhatabı olan mercilere fermanları hazırlanırd1.

Bahse konu meseleler, şayet Patriklik makamının yetki alanına giren ve kendilerine verilen tayin beratlarında açıkça ifade dilen tayin, azil, cezalandırma, nikâh, âyinlerine ait meseleler vs. hakkındaysa, hükümet tarafından hiçbir şekilde müdahale edilmezdi. Bu durumda "mûcebince şer'ile hüküm buyruldu"26, "derkenarı mûcebince kānun üzere yazıla"27 ya da "derkenarı mûcebince mâliyeden şürûtuyla hüküm buyruldu" ${ }^{28}$ gibi standart ifadelerle onay verilirdi. Kilise tamirine ait hususlarda ise, daha ayrıntılı buyuruldu kayıtlarını görmek mümkündür. Örneğin Kadıköy'deki Ermenilerin, kiliselerinin tamiri için yaptıkları müracaat hakkında şu karar verilmişti: "İ'lâmı mûcebince kilise-i mezkûrenin muhtâc-1 ta'mir olan mahalleri ber-mûceb-i fetevâ-y1 şerîfe müsâ'ade-i şer‘î olundığ 1 vechile bilâ-tevsi' ve lâ-terfi' vaz'-1 kadîmi üzere ta'mirine mümâna'at olunmamak içün deyü buyuruldu." ${ }^{29}$ Buyuruldusu ne şekilde yazılırsa yazılsın, bu araştırma için gözden geçirilen onlarca patrik arzuhâli arasında, Osmanlı Hükümeti tarafından uygun görülmeyerek reddedilmiş bir tek arzın bile bulunmaması oldukça dikkat çekicidir.

\section{Münasebetlere Tesir Eden Dinamikler}

Ermeni Patrikhanesi'nin devletle olan münasebetlerinin, ele alınan zamanın konjonktürel şartlarından ve dönemin devlet adamlarının şahsî tercihlerinden etkilenmesi tabiidir. Keza patriklerin idare tarzları ve cemaat içindeki dinî ihtilaflara yaklaşım şekillerinin de belirleyici olduğu kesindir. Bu hususlarda resmî belgelere yansıyan açık ifadelere nadiren rastlanır. Ama hadiselerin gelişim seyri takip edildiğinde, bazı genellemeler yapmak pekâlâ mümkündür.

Ele alınan dönemin genel görünümüne bakıldığında, 17. yüzyıl süresince Osmanlı Devleti'nin idarî, iktisadî ve içtimaî yapısında belirgin şekilde tahribata neden olan arızaların,

${ }^{20}$ Bursa, İzmir ve Ankara taraflarında Frenklik iddiaları hakkında Patrik IX. Hovhannes'in arzı: BOA, İbnülemin Dahiliye, nr. 2955 (1723).

${ }^{21}$ Kayseri'de eşkıyadan bazı kişilerin cemaate zulmü hakkında Patrik IX. Hovhannes'in arzı: BOA, KK, nr. 2542-8, s. 54a (1732).

${ }^{22}$ Ermeni cemaatinden kanun üzere vergi tahsili için, tarafina mutat dört adet emr-i şerîfin verilmesi hakkında Patrik IX. Hovhannes'in arz1: BOA, D.PSK, 12/1 (1740).

${ }^{23}$ BOA, İbnülemin Dahiliye, nr. 1863.

${ }^{24}$ BOA, D.PSK, $3 / 21$.

${ }^{25}$ BOA, D.PSK, 7/27.

${ }^{26}$ BOA, D.PSK, 2/89.

${ }^{27}$ BOA, D.PSK, 3/59.

${ }^{28}$ BOA, D.PSK, 3/150.

${ }^{29}$ BOA, İbnülemin Dahiliye, nr. 2082 (Mart 1721). 
yeni bir asra girilirken de mevcudiyetini büyük ölçüde koruduğu görülür. Her ne kadar batıda uzun süren savaşlar Karlofça ve İstanbul Antlaşmalarıyla sona ermiş olsa da, idareciler ve ahali savaş yorgunudur. Edirne Sarayı'na çekilen Sultan II. Mustafa, büyük ölçüde yönetimi paşalara ve Şeyhülislâm Feyzullah Efendi'ye devretmiştir. Rüşvet, yolsuzluk ve adam kayırma gibi hastalıklar, toplumun tüm kesimi gibi Ermeni ruhban ve cemaatini de tesiri altına almıştır. Birtakım çıkar gruplarının müdahalesine açık hale gelen Patriklik makamı için, ruhban arasında sert mücadele sürüp gitmektedir. 1715'e kadar devam eden yıllar boyunca çok sık aralıklarla görev değişikliklerinin yaşanması, cemaat için tam bir istikrarsızlık unsuru olmuştur. ${ }^{30}$ Yanı sıra cemaatin 18. yüzyılda karşılaştığı başlıca sorunlar arasında dinî taassup, kiliselerdeki makam ve mevkileri elde etme ihtirası, misyonerlik faaliyetleri ve mezhep farklılıkları, diğer gayrimüslim halkla yaptıkları alışverişler ve ticaret, ölen kişilerin terekelerine müdahale, Katolikleri destekleyen Fransızların manevî baskılarına karşı tepki gibi hususlar mevcuttu. ${ }^{31}$ Patriklerin, devlet adamlarıyla kurdukları ilişkiler ve cemaatin iç meselelerindeki şahsî yaklaşımları, Patrikhane'nin Osmanlı Hükümeti'yle olan münasebetlerine doğrudan tesir ediyordu. Bu bağlamda 18. yüzyılın ilk yarısında görev yapmış İstanbul Ermeni Patrikleri arasında üç ismin öne çıktığı görülür ki, bunlar Mıkhitar, I. Avedik ve IX. Hovhannes'tir.

Ermeni cemaatinin reforma ihtiyacı olduğu görüşünde olan Mıkhitar, patrik seçilmesine rağmen düşüncelerini gerçekleştiremeyince batıya gitmiş; orada kendi adıyla anılacak olan (Mikhitaristler) bir topluluk teşkil ederek, propaganda faaliyetlerini uzun süre devam ettirmiştir. ${ }^{32}$ Patrik I. Avedik ise, görev yaptığı zaman süresince gerek Latin kilisesine temayülü olan cemaat mensuplarına karşı takındığı sert tavır, gerekse dönemin bazı devlet görevlileriyle kurduğu münasebet vesilesiyle adından söz ettirmiştir. İlk patriklik devrinde, zamanın güçlü dinî-siyasî figürü olan Şeyhülislâm Feyzullah Efendi ile şahsî dostluk kurduğu bilinir. Zaten bu dönemin, 1703 'teki Edirne Vak'ası'yla nihayete ermesiyle birlikte, Avedik'in görevine de son verilmiştir. Yıllar sonra Kudüs Patrikliği'ndeki ihtilaflarla alakalı olarak, Kudüs'teki Ermeni cemaatinin İstanbul'a gönderdikleri müşterek bir arzuhâlde, I. Avedik'in Kudüs Patrikliği'ni kendi üzerine, Feyzullah Efendi vasıtasıyla tevcih ettirdiği söylenmiş; ayrıca ikinci defa göreve geldiği zamanki Kudüs'e hâkim olma teşebbüsünün ise, Veziriazam Çorlulu Ali Paşa'nın görev süresine tesadüf ettiğine dikkat çekilmiştir. ${ }^{33}$ Patrik IX. Hovhannes'in uzun görev yıllarının, Ermeni cemaati açısından yeniden derlenip toparlanma anlamı taşıdığı açıktır. Bu dönemde özellikle Lâle Devri'nin barış ortamından da istifade edilerek eğitim, yayın ve kültürel faaliyetlere ağırlık verilmiştir. ${ }^{34}$ Ermeni toplumunun zengin kesimi arasından çıkan ve Amiralar denilen kişiler, gerek doğrudan doğruya Sarayla, gerekse devlet adamlarıyla şahsî münasebetler ve iyi ilişkiler

\footnotetext{
${ }^{30} 1461$ 'den 1600 'e kadar sadece 16 patrik görev yaparken, 1600-1715 arasında bu makam 44 ayrı patrik arasında el değiştirmiştir. Bkz. George A. Bournoutian, Ermeni Tarihi, Ermeni Halklarının Tarihine Kısa Bakış, Çeviri: Ender Abadoğlu - Ohannes K1lıçdağı, Aras Yayıncılık, İstanbul 1011, s. 138.

${ }^{31}$ Tafsilat için şu çalışmaya da bakılabilir: İbrahim Güler, "XVIII. Yüzyıl Osmanlı Toplumunda Ermeniler: Gözlemler ve Düşünceler”, Hoşgörü Toplumunda Ermeniler, Cilt: 2, Kayseri 2007, s. 352.

32 Daha fazla malumat için bakılabilir: Gürsoy Şahin, Osmanlı Devleti'nde Katolik Ermeniler Sivaslı Mihitar ve Mihitaristler (1676-1749), IQ Kültür Sanat Yayınc1lık, İstanbul 2008; Bournoutian, Ermeni Tarihi, s. 139-140.

${ }^{33}$ BOA, D.PSK, 4/49. Hadiselerin tafsilatı için şu makaleye bakılabilir: Ensar Köse, "Bir Hayalin Peşinde Yüz Yı1: Kudüs ve İstanbul Ermeni Patrikliğini Birleştirme Çabaları (1650-1750)", İstanbul Üniversitesi Edebiyat Fakültesi Tarih Dergisi, Sayı: 63 (2016/1), İstanbul 2016, s. 55-76.

${ }^{34}$ 18. yüzyılda Ermenilerin matbaacılık faaliyetleri hakkında: Krikor Damatyan, "Patrik IX. Hovhannes Döneminde Yayın Faaliyetinin Gelişimi”, Hoşgörü Toplumunda Ermeniler, Cilt: 2, Kayseri 2007, s.467-481; Günay Göksu Özdoğan-Füsun Üstel-Karin Karakaşl1-Ferhat Kentel, Türkiye'de Ermeniler, Cemaat-Birey-Yurttaş, İstanbul Bilgi Üniversitesi Yayınları, İstanbul 2009, s. 66.
} 
kurarak, bazı araştırmacılar tarafından "Ermeni Rönesansı" ${ }^{35}$ şeklinde telakki edilecek olan parlak yı1ların yaşanmasına katkı sağlamışlardır. ${ }^{36}$

$\mathrm{Bu}$ genel manzara içinde şimdi de, araştırmanın asık kaynak malzemesini oluşturan patrik arzuhâllerine bakalım. Bu bağlamda araştırmanın tarih aralığı olarak, Patrik Mıkhitar'ın göreve başladığı 1699 yılından itibaren, Patrik IX. Hovhannes'in ölümü olan 1741 'e kadarki dönem belirlendi. Başbakanlık Osmanlı Arşivi'ndeki Bâb-1 Defteri Piskoposluk Kalemi dosyaları (D.PSK) ile, bu kalemden çıkan hüküm kayıtlarını muhtevî Piskoposluk Defterleri (Kamil Kepeci tasnifinde) sistematik olarak tarandı. Ayrıca Bâb-1 Âsafî Divan (Beylikçi) Kaleminden (A.DVN) bazı dosyaların yanı sıra, müteferrik belgeler sunan Cevdet ve İbnülemin kataloglarından çıkarılan belgeler de ilave edildi. Böylece oluşturulan zengin arşiv malzemesi içinde, belirtilen tarih aralıklarında görev yapmış İstanbul Ermeni Patrikleri tarafından Osmanlı resmî makamlarına sunulmuş toplam 242 arzlarzuhâl olduğu görüldü. Mamafih patrik arzları sadece bunlardan ibaret olmasa gerektir. Ama bu çalışma için elde edilebilenler bu kadardır. Arzuhâllerin, adet ve yüzdelik olarak, sırasıyla görev yapan patriklere göre dağılımı Tablo 1'de verilmiştir.

\begin{tabular}{|c|l|c|c|}
\hline \multicolumn{2}{|c|}{ Patrik } & Arz Adedi & Oranı (\%) \\
\hline 1 & Mikhitar & 11 & 4,54 \\
\hline 2 & Yeprem & 2 & 0,82 \\
\hline 3 & Avedik I & 30 & 12,39 \\
\hline 4 & Kalusd I & 4 & 1,65 \\
\hline 5 & Nerses I & 1 & 0,41 \\
\hline 6 & Mardiros III & 3 & 1,23 \\
\hline 7 & Mikael I & 4 & 1,65 \\
\hline 8 & Sahak I & 1 & 4,54 \\
\hline 9 & Hovhannes VII & 5 & 0,41 \\
\hline 10 & Hovhannes VIII & 170 & 2,06 \\
\hline 11 & Hovhannes IX & $\mathbf{2 4 2}$ & 70,24 \\
\hline \multicolumn{2}{|c|}{ Toplam } & \\
\hline
\end{tabular}

Tablo 1: 1699-1741 yılları arasındaki toplam 242 adet patrik arzuhâlinin dağılımı.

Burada yer alan arzuhâl sayıları, kuşkusuz patriklerin görev sürelerinden bağımsız değildir. Örneğin IX. Hovhannes'e ait bu kadar fazla arz bulunması, onun uzun yıllar görev yapmış olması keyfiyetiyle açıklanabilir. Ama yine de söz konusu arzuhâller, aynı zamanda cemaatin karşı karşıya bulunduğu meseleler hakkında patriklerin şahsî yaklaşımlarına dair bazı ipuçları da verir. Katolik kilisesine temayülün, ruhaniler arsında günden güne yaygınlık kazanması ve ayrıca yozlaşma belirtilerinin artışını, patrik arzlarında açık şekilde görmek mümkündür. Patrik Mıkhitar'ın 1699'da cemaati ifsad eden Papas Teotoros'un sürgüne gönderilmesi talebi ${ }^{37}$ ile âyinlerine muhalif nikâh akdiyle mücadelesi ${ }^{38}$ bu neviden örneklerdendir. Ruhban ve cemaat sorunlarına karşı daha da belirgin ve sert tavır, Patrik I. Avedik tarafından sergilenmiștir. Özellikle göreve geldiği 1702 tarihinden itibaren, Latinlik temayülü olduğu anlaşılan ruhanileri

\footnotetext{
${ }^{35}$ Aslen Kayseri kökenli ve 18. yüzyıl sonunda İzmir'e yerleşmiş bir aileden gelen Gerard Dedeyan'ın derlemesi olan hacimli eserin 11. Bölüm başlığına "Ermeni Rönesansı" adı verilmiştir. Bkz. Ermeni Halkının Tarihi, Derleyen: Gerard Dedeyan, Fransızca'dan Çeviren: Şule Çiltaş, Ayrıntı Yayınları, İstanbul 1015, s. 399 vd.

${ }^{36}$ Düzyan ailesinin Saray ve Sultan III. Ahmed'le iyi münasebetleri hakkında: Rahip G. Çarkçıyan, Türk Devleti Hizmetinde Ermeniler, Kesit Yayınları, İstanbul 2006, s. 43; Recep Çelik, "Osmanlı Bürokrasisinde Görev Yapan Ermeniler”, Hoşgörü Toplumunda Ermeniler, Cilt: 4, Kayseri 2007, s. 27-53.

${ }^{37}$ BOA, Mühimme Defteri (MD), nr. 111, s. 258.

${ }^{38}$ BOA, İbnülemin Dahiliye, nr. 1241.
} 
görevden alma ve cezalandırma talebiyle hükümete peş peşe arzlar sunmuştur. ${ }^{39} \mathrm{~K}$ ısa süre görev yapan I. Nerses'in tek arzuhâli, Kars ve Çıldır Marhasası Daniel'in beratının yenilenmesi; ${ }^{40}$ VII. Hovhannes'in ise Tokat'a marhasa tayini hakkındadır. ${ }^{41}$

\begin{tabular}{|c|l|c|c|}
\hline \multicolumn{2}{|c|}{ Arzuhâlin Muhtevası } & Arz Adedi & Oranı (\%) \\
\hline 1 & Marhasa (Tayin, Azil, İhtilaflar) & 129 & 53,30 \\
\hline 2 & Kudüs Patrikliği & 31 & 12,80 \\
\hline 3 & Ruhban (Rahib, Papas, Karabaş) & 21 & 8,67 \\
\hline 4 & Vergiler & 20 & 8,26 \\
\hline 5 & Eçmiyadzin Katogigosluğu & 14 & 5,78 \\
\hline 6 & Frenklik & 6 & 2,47 \\
\hline 7 & Akçeli İşler & 4 & 1,65 \\
\hline 8 & Nikâh & 4 & 1,65 \\
\hline 9 & Adalet Talebi & 4 & 1,65 \\
\hline 10 & Cezalandırma (Hapis, Sürgün) & 3 & 1,23 \\
\hline 11 & Kilise (Tamir, Vakfi) & 3 & 1,23 \\
\hline 12 & Patriklik Makamı & 2 & 0,82 \\
\hline 13 & Süryaniler & $\mathbf{2 4 2}$ & 0,41 \\
\hline \multicolumn{2}{|c|}{ Toplam } & 1 & \\
\hline
\end{tabular}

Tablo 2: 1699-1741 yılları arasındaki toplam 242 adet patrik arzının muhteva dağılımı.

İstanbul Ermeni Patriklerinin Osmanlı Hükümeti'ne sundukları arzlar, muhtevaları yönünden incelendiğinde, Tablo 2'de görüleceği üzere, yarıdan fazlasının marhasalara dair olduğu anlaşılır. Aslında bu durum şaşırtıcı değildir. Zira her ne sebeple olursa olsun tüm ruhbanın azil ve tayin işleri, Patrikhane tarafından yapılır ve Sarayın onayına sunulurdu. İstanbul Patriklerinin yazışmalarına konu olan diğer başlıca mevzuların ise, Kudüs Patrikliği'ne ait meseleler, ${ }^{42}$ marhasaların haricinde kalan diğer ruhban sınıfının sorunları, ${ }^{43}$ vergiler, ${ }^{44}$ Eçmiyadzin Katogigosluğu ${ }^{45}$ Frenklik ve Latinlik iddiaları, ${ }^{46}$ bazı akçeli işler ${ }^{47}$ ve nikâh akdi ${ }^{48}$ gibi hususlar olduğu görülür. Patrik arzlarının muhtevaları incelenerek hazırlanan ve yukarıdaki tabloda görülen verilerin, 18. yüzyılın ilk yarısı itibariyle İstanbul Patrikliği ve genel olarak Ermeni ruhban ve cemaatinin, Osmanlı Hükümeti ile münasebetlerine tesir eden müşahhas dinamikler olduğunu söylemek mümkündür. Aslında sıralanan bu meselelerin her biri hakkında, tafsilatlı araştırmalar yapmayı mümkün kılacak kadar belge vardır. Fakat bu çalışmada, sadece ilk altı sırada yer alan meselelere kısaca temasla yetinilecektir.

${ }^{39}$ Bu hususta birkaç örnek: Hasankale Meryem Ana Manastırı'na yeni marhasa tayini (BOA, D.PSK, 2/60); Zile'de Papas Garabed ve Kolı'nın görevden azli (D.PSK, 2/82); sâbık Sis Marhasası Krikor'un cezalandırılması talebi (D.PSK, 2/88); Frenk âyininde olan kişilerin cezalandırılması talebi (D.PSK, 2/89).

${ }^{40}$ BOA, D.PSK, $3 / 47$.

${ }^{41}$ BOA, Cevdet Adliye, nr. 4780.

${ }^{42}$ Kudüs'teki cemaat için tasadduk cem'i hakkında Patrik I. Sahak'ın arzı: BOA, KK, nr. 2542-2, s. 69 (1713).

${ }^{43}$ Erzincan Çanlı Kilise papasının sürgün edilmesi hakkında Patrik IX. Hovhannes'in arzı: BOA, Cevdet Adliye, nr. 3034 (1716).

${ }^{44}$ Amasya ve Merzifon'da vergi tahsili hususunda yaşanan sıkıntılara dair Patrik I. Avedik'in arzı: BOA, D.PSK, 3/90 (1705).

${ }^{45}$ Eçmiyadzin Kilisesi için tasadduk cem'i hakkında Patrik IX. Hovhannes'in arzı: BOA, A.DVN, 1138/61 (1725).

${ }^{46}$ Frenk âyinine giren râhibin Bozcaada Kalesi'ne hapsedilmesi hakkında Patrik IX. Hovhannes'in arzi: BOA, $K K$, nr. 2542-8, s. 35b.

${ }^{47}$ Bolu'da ölen Râhib Odanis'in mallarına el konulmasına dair Patrik I. Sahak'ın arzı: BOA, KK, nr. 2542-2, s. 58 (1712).

${ }^{48}$ İzmir ve havalisinde bazı kişilerin, âyinlerine aykırı nikâh isteğinde bulunmalarına dair Patrik IX. Hovhannes'in arzı: BOA, Cevdet Adliye, nr. 77 (1722). 


\section{A. Marhasalara Ait Meseleler}

Ermeni kilise hiyerarşik düzeninde, cemaat mensupları ile patrik arasında irtibatı sağlayan kişilere marhasa denirdi. ${ }^{49}$ Marhasalar, İstanbul Ermeni Patriği'nin taşradaki temsilcileri olarak görev yaparlardı. Aslında Ermeni kilisesinin ruhanî yapısında böyle bir makam yoktu. Muhtemelen Osmanlı Devleti'nin, cemaati idare etmede uyguladığı pratik bir idarî yapılanma olsa gerektir. Nitekim Rum Ortodoks cemaati için de, marhasalığın müteradifi olarak metropolitlik tesis edilmiştir.

Marhasalar hakkındaki toplam 129 arzın \% 75'lik gibi büyük bir kısmı, azil ve tayinler hakkındadır. Marhasa tayin sebepleri arasında ilk sırada, görevden alma (azil) geliyordu. Azil sebeplerinin başında ise, âyinleriyle alâkalı hususlarda ihmal ve yetersizliği görülme ve ayrıca kilise cemaatiyle aralarındaki anlaşmazlıklardan mütevellit sebepler yer alıyordu. Daha önce de bir nebze işaret edildiği üzere, yeni göreve gelen patriklerin öncelikli işlerinden birisi, Patrikhane'ye bağlı kilise ve manastırlarda kendi görüşlerine uygun ruhban kadrosunu tesis etmekti. Bunu sağlamak için çeşitli bahanelerle mevcut marhasalardan birçoğunun görevine son verilerek yenileri atanıyordu. Görevden alma nedenleri, patrik arzlarında çoğunlukla ifade edilirdi. Patrik Mıkhitar, Halep Ermeni Marhasası Yeprem'i "câhil ve Ermeni âyinini icrâya iktidarı" olmadığ $1{ }^{50}$ Patrik I. Avedik, Karahisarışarki Marhasası Gabriel'i "nâ-müstahak" olduğu; ${ }^{51}$ Patrik I. Kalusd, Hasankale Marhasası Teotoros'u manastır eşyalarını "kendü hevâsına harc ve sarf" ettiği; ${ }^{52}$ Patrik VIII. Hovhannes ise Erzincan Marhasas1 Minas'1, "âhar marhasalığa yolu" geldiğ $i^{53}$ gerekçelerine istinaden görevden almıştı. Mamafih bazen neden belirtilmeden, "âyinleri üzere azli lâzım gelmekle" şeklinde genel ifadelerle geçiştirildiği de olurdu. ${ }^{54}$ Ama her ne şekilde olursa olsun, netice itibariyle bu neviden tasarruflar patriğin beratına dâhil yetkilerden olduğundan, Osmanlı Hükümeti tarafindan müdahale edilmezdi. Marhasa tayinlerinde karşılaşılan yaygın bir durum da, görevi devam ederken ölen kişilerin yerlerine atama yapılmasıydı. Özellikle cemaatin çalkantılı döneminin ardından 1716' da işbaşına gelen Patrik IX. Hovhannes, görev süresinin ilk yıllarında marhasa tayinlerinde, azil yerine ölüm veya başka sebeplerle boş kalan kadrolara atama yöntemini tercih etmiştir. ${ }^{55}$ Bunun yanı sıra, bir marhasalık idaresine bağlı kilise veya manastıra ait köy ve kasabaların idarî yönden nereye bağlı bulunduğuna dair ihtilaflar da eksik olmuyordu. Bu gibi konularda İstanbul Patriği'nin sunduğu arzuhâle karşılık olarak, Piskoposluk Kalemi tarafından ihtilaflı meselenin aslı ne minvalde ise kaydı çıkarılarak cevap yazılırd $1 .{ }^{56}$ Görevden kaçma, ${ }^{57}$ faaliyetlerinden ötürü dava konusu olmalar1, ${ }^{58}$ marhasaların tayini ve görev yapmalarına hariçten müdahalenin men'i ${ }^{59}$ marhasalıklarda şarap

\footnotetext{
${ }^{49}$ Tafsilat için bakılabilir: Davut Kılıç, Tarihten Günümüze Istanbul Ermeni Patrikhanesi, s. 67.

${ }^{50}$ BOA, D.PSK, $1 / 183$ (8 Şubat 1700).

${ }^{51}$ BOA, D.PSK, $2 / 58$ (9 Nisan 1702).

52 BOA, D.PSK, 2/172 (14 Kasim 1703).

${ }^{53}$ BOA, Cevdet Adliye, nr. 3351 (3 Temmuz 1714).

${ }^{54}$ Patrik IX. Hovhannes'in arzı üzerine, Diyarbakır Ergani Marhasası Bedros'un yerine Daniel'in tayin edilmesi hakkında: BOA, $K K$, nr. 2542-1, s. 78 (3 Ağustos 1719).

55 Ölen marhasanın yerine atama yapılması hususunda birkaç örnek: Pasinler kazasındaki Ağca Manastır'ın ölen marhasası Osib'in yerine 5 Nisan 1716'da Râhib Sahak'1n (BOA, D.PSK, 5/86); Karahisarışarki'de marhasa Avedik'in ölümü üzerine, yerine 17 Mayıs 1716'da Ohan'ın (BOA, Cevdet Adliye, nr. 1023); Erzurum'da Kızılkilise Marhasas1 Garabed'in ölümü üzerine, yerine 1 Ocak 1718 tarihinde Râhib Krikor'un (BOA, $K K$, nr. 2542-1, s. 42) tayin edilmeleri. ${ }^{56}$ Uşak ve Ankara marhasalıklarındaki bazı ihtilaflar hakkında Patrik IX. Hovhannes'in müracaatına verilen cevap: BOA, $K K$, nr. 2542-1, s. 65 (1719); Karahisarışarki'de marhasalık ihtilafina dair Patrik IX. Hovhannes'in arzı: BOA, Cevdet Adliye, nr. 51 (1722).

${ }^{57}$ Görev yerlerine gitmeyerek kaçan marhasalar hakkında Patrik IX. Hovhannes’in arzı: BOA, D.PSK, 6/24 (1717).

${ }^{58}$ Rodosçuk marhasasına dava açılmasına dair Patrik IX. Hovhannes'in arzı: BOA, Cevdet Adliye, nr. 3489 (1721).

${ }^{59} \mathrm{Bu}$ hususta Patrik IX. Hovhannes'in arzı: BOA, D.PSK, 8/93 (1725); Halep marhasasına hariçten bazı kişilerin müdahalesinin men'i hakkında Patrik IX. Hovhannes'in arzına cevap: BOA, KK, nr. 2542-8, s. 66a (1733). Keza marhasa tayinine hariçten müdahale edilmemesi isteğini hâvî Patrik IX. Hovhannes'in arzi: BOA, D.PSK, 11/169 (1740).
} 
imali $^{60}$ ve yol emniyeti ${ }^{61}$ gibi hususlar da, Patrikhane ile Hükümet arasındaki yazışmaların belli başlı konularındandı.

\section{B. Kudüs Patrikliği İle Alakalı Meseleler}

Kudüs, Ermenilerin İstanbul'dan sonraki diğer ana patriklik merkezi olup, buraya bağlı yerler arasında Beytlehem, Remle, Yafa, Beyrut, Kıbrıs, Lazkiye, Şam ve Misır bulunuyordu. ${ }^{62}$ Kudüs Ermeni Patrikliği, 18. yüzyıl başlarına kadar İstanbul'dan ayrı şekilde idare ediliyordu. Göreve tayin edilecek patrikler hazineye 11.900 akçe âdet-i pişkeş öderlerdi. ${ }^{63}$ Patrikler, haklarında azli gerektirecek mücbir bir sebep olmadıkça, ölünceye kadar göreve devam etmek üzere atanırlardı. Patriğin ölümü halinde ise, Kudüs’te buluna ruhaniler kendi aralarında bir rahibi seçerler ve onay için Osmanlı Hükümeti'ne teklifte bulunurlardı. Şu halde Kudüs Ermeni Patrikliği, teşkilat yapısı ve idaresi bakımından bağımsız durumdaydı. Aslında bu yönüyle İstanbul Ermeni Patrikleri'nin sundukları arzuhâllere konu olmaları beklenmezdi. Ancak fiiliyattaki durum böyle değildi. Zira Kudüs Patrikleri, devletle halledilmesi gereken işlerinde sıklıkla İstanbul Patriği'nin tavassutuna ihtiyaç duyarlardı. Ayrıca cemaat mensuplarından, Kudüs'teki kiliseler için yardım toplama faaliyeti, bir şekilde Patrikhane'yi de alakadar ediyordu. Ama şüphesiz 18. yüzyıl başlarında, Kudüs Patrikliği'ni İstanbul'un gündemine sokan asıl mesele, bu iki kurumu birleştirmeye mâtuf teşebbüsler olmuştur.

18. yüzyıla girilirken Kudüs Ermeni Patrikliği makamında Râhib Minas oturuyordu ${ }^{64}$ Fakat Patrikliğin idaresinde görülen birtakım zafiyet, özellikle de suiistimaller sebebiyle kilise ve manastırların duçar olduğu ekonomik sıkıntılar, İstanbul'da Patrik I. Avedik'in dikkatini çekmişti. Göreve tayin edildiği 7 Mart 1702 tarihini takip eden aylarda, Kudüs meselesiyle alakalı olarak peş peşe arzlar sunmaya başlayan Avedik'in asıl niyetinin, Kudüs'ün idaresini de uhdesine almak olduğu açıktır. Nitekim Divân-1 Hümâyun'a sunduğu 12 Ağustos 1702 tarihli arzuhâlde Avedik kendi unvanını, "Patrik-i Ermeniyân-1 İstanbul [ve] hâlâ Kudüs-i Şerîf" şeklinde yazdığına göre ${ }^{65}$ bu emeline ulaşmış olmalıdır. Ne var ki Kudüs'ün İstanbul'a bağlanması meselesi, bir nevi Patrik I. Avedik'in şahsî teşebbüsü olmaktan öteye geçemediğinden, onun ilk görevinin sona ermesiyle askıya alınacak; ardından 1705'te tekrar Patrik olunca yeniden icraya konulacaktır. ${ }^{66}$ Kudüs'e ruhban tayininde İstanbul Patrikliği'nin sıklıkla müdahil olması $;{ }^{67}$ kilise tamiri için toplanan yardım paralarının harcanmasında ortaya çıkan suiistimaller, ${ }^{68}$ Kudüs’teki ruhban ve yardıma muhtaç cemaat mensupları için tasadduk cem' $i ;{ }^{69}$ kilise ve manastırların borçlar ${ }^{70}$ gibi meseleler nedeniyle Kudüs Ermeni Patrikliği, İstanbul Patrikhanesi'nin hükümetle münasebetlerinde daima önemli bir dinamik olmaya devam edecektir. ${ }^{71}$

${ }^{60}$ Marhasaların vakıf bağlarından şarap imali hakkında Patrik IX. Hovhannes'in arzı: BOA, KK, nr. 2542-8, s. 60 b (1732).

${ }^{61}$ Tekirdağ marhasasının yollarda rahatsız edilmemesine dair Patrik IX. Hovhannes'in arzına cevap: BOA, $K K$, nr. 2542-8, s. 74a (1734).

${ }^{62}$ Canan Seyfeli, İstanbul Ermeni Patrikliği, s. 95.

${ }^{63}$ BOA, D.PSK, $1 / 168$

${ }^{64}$ BOA, D.PSK, $2 / 63$

${ }^{65}$ BOA, D.PSK, $2 / 90,99$

${ }^{66}$ BOA, D.PSK, $3 / 77$.

${ }^{67}$ Kudüs Patrikliğine Râhib Matteos'un tayin edilmesine dair: BOA, D.PSK, $3 / 158$ (1706).

${ }^{68} \mathrm{Bu}$ hususta Patrik I. Avedik ile sâbık Kudüs Patriği Kalusd arasındaki karşılıklı ithamlar: BOA, D.PSK, $3 / 106$ (4 Kasim 1705).

${ }^{69}$ BOA, D.PSK, 3/113.

${ }^{70}$ BOA, D.PSK, 1/100 (1 Aralık 1688).

${ }^{71}$ İstanbul Ermeni Patrikliği ile Kudüs arasındaki münasebetlerin seyri ve bu iki patrikliği birleştirme çabaları hakkında şu çalışmada ayrıntılı bilgi bulunabilir: Ensar Köse, "Bir Hayalin Peşinde Yüz Yı1: Kudüs ve İstanbul Ermeni Patrikliğini Birleştirme Çabaları (1650-1750)”, s. 41-88. 


\section{Ruhbana ve Cemaate Ait Sorunlar}

İstanbul Ermeni Patrikleri'nin karşılaştıkları önemli meselelerden birisi de ruhban sınıfı (râhib, papas, karabaş) ve cemaat içindeki yozlaşmaydı. Ruhanilere yakışmayan ve nefsanî zafiyet eseri olan bazı fiillere tevessül etme, ${ }^{72}$ çeşitli bahanelerle görevden kaçma ${ }^{73}$ ve benzeri nâhoş davranışlar; bunlara karşı birer müeyyide olarak ruhban sınıfından kişilerin çeşitli suç isnadıyla cezalandırılmas ${ }^{74}$ veya cezalarının affi $^{75}$ gibi hususlar, hükümete sunulan patrik arzlarına konu teşkil ediyordu. Kiliseye bağlı cemaatin evlilik ve nikâh meselesi de, Ermeni din adamlarının takip etmek zorunda oldukları işlerdendi. Bu durum patrik ve marhasalara verilen beratlarda da açı biçimde yazılırdı. Buna rağmen cemaatten zaman zaman âyinleri ve kanuna muhalif şekilde nikâh kıydıranların olması, şikayetlere konu oluyordu. İstanbul Patriği Mıkhitar'ın Divân-1 Hümâyun'a sunduğu bir arzuhâldeki şu ifadeler oldukça dikkat çekicidir:

"Bu kulları Ermeni Patriği olup âyinimize muhâlif aramızdan ba'zıları hâricde olan kefereye âyinimize mugāyir âhar yerlerde nikâh etdirüp bu makūlelerin men 'i bâbında yedime fermân-ı âlî ihsân olunmağla merhametlü Sultânımdan mercûdur ki İstanbul Kädısı ve Galata ve Eyyüb ve Üsküdar Kädısı taraflarından mahalle imamlarına taraf-ı şer 'iyyeden tenbih buyurlup hilâf-ı emr-i âlî âyinimize muhâlif olanlara nikâh olunmamak bâbında fermân-ı şerîfleri recâ olunur. "'76

Bu nevi taleplere, daha önce patriğe verilmiş olan berata bakılarak gerekli cevaplar yazılırdı. Nitekim Patrik Mikhitar'ın bu arzına da, “Ermeniyân-1 İstanbul Patriği olanlara verilen berâtlarında âyin-i bâtıllarına muhâlif nikâh câiz olmayan kefereye nikâh eylemeyeler deyü tasrih" oluna-geldiğinden, buna muvafık ş̧ekilde cevap yazılmıştır. Yani Osmanlı Devleti açısından dikkat edilen şey, yıllardan beri süregelen uygulama (kānun-ı kadîm) ve berat-ı şerîfe aykırılık teşkil etmemesi; ayrıca genel bir prensip olarak, bu gibi hususlar cemaatin kendi iç düzeniyle alakalı bir mesele olduğundan, dışarıdan müdahil olunmaması keyfiyetiydi. Ama hükümet tarafindan müdahale olsun veya olmasın, bundan sonra da zaman zaman cemaat mensupları arasında âyinlerine muhalif şekilde nikâh kıydıranlar olmuş ve İstanbul Patrikleri de bunlarla mücadele etmeyi sürdürmüşlerdir. ${ }^{77}$

\section{Akçeli İşler}

Patriklik makamının asıl uğraşı her ne kadar doğası gereği "ulvî” konular olsa da, Osmanlı idarî düzenlemesinin mücbir yapısı ve ayrıca yüzyıllardan beri süregelen yardım ve bağış toplama ve kabulü ${ }^{78}$ gibi ihtiyarî sebeplerden ötürü, parayla alakalı "akçeli işler" de hıristiyan din adamlarının faaliyetlerinin ayrılmaz bir parçası olmuştur. İstanbul Ermeni Patriği, kendisine bağlı cemaat mensuplarının vergilerini tahsil etmek şartıyla göreve tayin edilirdi. Bu nedenle, tayin şartlarının gereğini yerine getirmesi ve cemaatten toplanan verginin hesabını düzgün tutarak, hazine ile muhasebesini vaktinde görmesi oldukça mühimdi. Muhasebe hususunda gevşekliği görülen patriğin görevini sürdürmesi zordu. Nitekim Patrik I. Avedik'in 1703'te görevden azlinde, diğer başka sebeplerin yanı sıra hazineye, "mîrî pişkeş ve maktu'undan bir akça ve bir habbe" vermemesinin de tesiri olmuştu. ${ }^{79}$ Vergi tahsil edebilmek için İstanbul Ermeni Patriği'ne

\footnotetext{
${ }^{72}$ Tokat'ta hırsızlık suçlamasıyla bir papasın Samsun Kalesi'ne hapsi hakkında Patrik IX. Hovhannes'in arzı: BOA, D.PSK, 9/63 (1730).

${ }^{73}$ Bazı karabaşların görev yerlerine gitmediklerine dair Patrik I. Sahak'ın arzı: BOA, KK, nr. 2542-2, s. 53 (1711).

${ }^{74}$ Fesat çıkaran Râhib Mikael'in Ahtamar'a sürgün edilmesi hakkında Patrik IX. Hovhannes'in arzı: BOA, D.PSK, 7/129 (1723).

75 Daha önce Limni adasına sürgün edilen Râhib Minas'ın affedilmesi talebini hâvî Patrik IX. Hovhannes'in arzı: BOA, İbnülemin Dahiliye, nr. 2462 (1720).

${ }^{76}$ BOA, İbnülemin Dahiliye, nr. 1241 (11 Mart 1700).

${ }^{77}$ Patrik III. Mardiros'un bu husustaki talebi: BOA, D.PSK, 3/150 (1706); İzmir dolaylarında bazı kişilerin âyinlerine aykırı şekilde nikâh kıydırmak istediklerine dair Patrik IX. Hovhannes'in arzı: BOA, Cevdet Adliye, nr. 77 (1722).

${ }^{78}$ Patrik IX. Hovhannes, Temmuz 1720'de hükümete sunduğu bir arzda, Rumeli vilayetlerindeki bazı râhib ve papasların, yardım toplama faaliyetleri sırasında cemaat mensuplarına baskı yapmalarından şikayetçi olmuştu (BOA, A.DVN, 812/82).

${ }^{79}$ BOA, D.PSK, 3/88.
} 
her yılın sonunda, gelecek seneye ait dört adet ferman verilirdi. Bu fermanlar, patriğin hükümete sunduğu arzuhâle karşı1ık olarak hazırlanırdı. Örneğin Patrik IX. Hovhannes'e 3 Aralık 1719 tarihinde verilen ferman, Piskoposluk Kalemi Defteri'nde şu klişe ifadelerle yer almıştır:

"Hâlâ İstanbul ve tevâbi i Ermeniyân patriği Hovhannes nâm râhib der-i sa âdetime memhûr arzuhâl sunup senevî cânib-i mîrîye maktu' 'u olan yüz kurk bin akça mukābelesinde beher sene mu 'tad-ı kadîm üzere verilecek dört kıt'a evâmir-i şerîfeyi bin yüz otuz iki senesine mahsub olmak üzere verilmek bâbında istid 'â-yı inâyet etmekle..."

$\mathrm{Bu}$ şekilde alınan fermanla, vergi tahsiline başlanırdı başlanmasında da sıkıntılar eksik olmuyordu. Özellikle 18. yüzyıl başlarında sık aralıklarla görev değişikliğinin yaşanması, patriklerin hazine ile olan hesaplarında bazı karışıklıklara ve anlaşmazlıklara sebep olmuştu. Nitekim I. Avedik'ten sonra Eylül 1703'te göreve gelen Patrik I. Kalusd, 140.000 akçe ödenmesi karşılığı olarak verilen dört adet fermanla ilgili, sâbık patrikle aralarındaki ihtilafı bir arzuhâlle hükümete bildirmişti. ${ }^{81}$

Diğer başka kesimlerden olduğu gibi, Ermeni cemaati mensuplarından da vergi ödemeye karşı zaman zaman direnç ortaya çıkıyordu. ${ }^{82}$ Ayrıca eskiden beri câri olan vergi miktarından fazla olarak cemaatten para tahsil etmek isteyen ruhbanın, bu nevi kanunsuz icraatları da bir şekilde hükümete intikal ediyordu. Hasankale'de Meryem Ana Kilisesi Marhasas1, Hasankale Beyi'ne maktû olarak tahsis edilen 60.000 akçeye kanaat etmeyerek, kendisinin fazla para talebiyle rahatsız edildiğinden yakınmış; buna karşılık Erzurum valisi ve kadısına yazılan hükümde, icmal defterlerinde yazılandan fazla talepte bulunulmaması emredilmişti. ${ }^{83} 1721$ ' de ise Patrik IX. Hovhannes bir arzuhâlinde, İznikmid ve Kütahya taraflarındaki râhib ve papasların, "kadîme mugāyir ziyâde talebiyle rencîde ve ta ‘addî eylediklerini" bildirmesi, bu gibi yakınmadan başka bir şey değildi. ${ }^{84}$

Osmanlı Hükümeti ile Patrikhane arasındaki yazışmalara konu olan malî meseleler, elbette sadece vergiden ibaret değildi. Ruhbanın zimmetine para geçirmesi ve suiistimaller gibi hususlara da sıkça rastlanıyordu. 1699'da Bursa Marhasası Sukyas'1n zimmetinde, geçen seneye ait vergi borcu kaldığından, bunun tahsili hususunda yardım talep edilmişti. ${ }^{85} 1702$ 'deyse İstanbul Ermeni Patriği Gapanlı Yeprem bir arzuhâlinde, Sivas Marhasası Sahak'ın, kilise mallarını kendi nefsi için sarf ederek manastırı büyük borca soktuğunu söylemişti. ${ }^{86}$

\section{E. Katolik Misyonerlerin Faaliyetleri}

Gregoryen ve Katolik Ermeniler arasındaki çekişmeler, 18. asır başlarında İstanbul Ermeni Patrikhanesi'nin ciddi baş ağrılarından birisiydi. Zira bu mesele, daha patrik seçiminde belirleyici bir kriter olmakla kalmıyor, aynı zamanda göreve getirilen kişilerin ruhban ve cemaat üzerinde otorite kurmalarında da etkili oluyordu. Osmanlı Devleti aslında genel bir kaide olarak, meselenin dinî yönüne girmiyor, bunu Ermeni cemaatinin kendi iç sorunu olarak görüyordu. Bununla birlikte, reayanın haklarına tecavüz halinde veya faaliyetlerin düzeni bozucu mahiyete erişmesi durumunda, ancak patrik veya cemaat mensuplarının müracaatı üzerine hadiseye müdahil oluyordu. Ama yine de Ermeni cemaatinin temsilcisi olarak Gregoryen Ermeni Patriği'ni muhatap alıyor ve süregelen düzenin bozulmasına mümkün mertebe firsat vermiyordu. Bunun için Katolikler üzerinde baskı kurularak, imparatorluk sınırlarında yeni yayılma alanları bulmalarına

\footnotetext{
${ }^{80}$ BOA, $K K$, nr. 2542-1, s. 85.

${ }^{81}$ BOA, D.PSK, $3 / 27$ (1704).

${ }^{82}$ Amasya ve Merzifon taraflarında vergi tahsilindeki sıkıntılara dair Patrik I. Avedik'in arzı: BOA, D.PSK, 3/90 (1705).

${ }^{83}$ BOA, $K K$, nr. 2542-1, s. 1 (27 Haziran 1700).

${ }^{84}$ BOA, $K K$, nr. 2542-1, s. 123-124.

${ }^{85}$ BOA, İbnülemin Dahiliye, nr. 1811 (22 Temmuz 1699).

${ }^{86}$ BOA, D.PSK, 2/44.
} 
mâni olunmaya çalışılıyordu. Fakat tüm engelleme çabalarına rağmen, bu mezhebe meyleden ruhban ve cemaat mensupları ise, çeşitli şekillerde cezalandırılıyordu. ${ }^{87}$

Ermeni ruhban ve cemaat mensupları arasinda Katoliklik propaganda ve faaliyetleri 18. yüzy1l öncesinde de görülmekle birlikte, ${ }^{88}$ Râhib I. Avedik'in 1702'de İstanbul Ermeni Patriği olmasından sonra daha belirgin hale gelmiștir. Zira sıkı bir Ortodoks olan I. Avedik, Katoliklere karş1 alabildiğine sert davranmaktan çekinmeyen bir kişiliğe sahipti. Zaten bu mücadeleyi daha Erzurum'da râhib olarak görev yaparken başlatmış, hatta patrik tayin edilmesi hususunda Divân1 Hümâyun'a sunduğu arzuhâlde, Erzurum'da Frenkliğe dâhil olmuş kişileri "nasihat ile yola getirdiği"ni ifade ederek, İstanbul'daki Ermeni taifesinin iki firkasından birinin Frenk dinine girdiğini söyleyerek, bunlarla mücadele etmek istediğini belirtmişti. ${ }^{89}$ Nitekim patrik olmasıyla birlikte Anadolu'daki marhasaları peş peşe görevden almaya başladı. Marhasalardan Karahisarışarki'de Rahib Gabriel'i "nâ-müstahak"; 90 Erzurum Hasankale'de Aharon'u "Frenk âyinine tâbi' ve re'âyâyı ihtilâle verdiği",;1' Zile'de papaslardan Karabet ve Kolı'yı ise "âyinlerine muhâlif hareket edüp ve âyinlerine mugāyir oldukları" "92 gerekçeleriyle azletti. Ayrıca 1702 senesi içinde Divân-1 Hümâyun'a sunduğu bir dizi arzuhâlle, Frenkler hususunda daha sıkı tedbirler alması için hükümeti harekete geçirmeye çalıştı. Daha önce Halep ve Sis taraflarında görevli olan Rahib Krikor'un, "Frengistana varup Papa'ya tâbi" olduğunu; sonra geri dönerek Ermeni cemaatine, "Frenk âyinine dönün ve bana tâbi " olun ve nasîhatimi kabul edin" diye baskı yaptığını iddia etti. ${ }^{93}$ Patrik I. Avedik' in Temmuz 1702 tarihli bir arzuhâldeki ifadelerine bakılırsa, tüm gayretine rağmen Katolikliğe temayülün önünü alamadığı görülür. Söz konusu arzuhâlde aynen şunları yazmıştı:

"Bu râhib kullarına bin yüz on üç Şevvâlinin yedinci gününde Ermeniyân üzerine İstanbul ve tevâbi 'i patrikliği ihsân olınup yedimde olan berat-ı âli-şân mûcebince mukaddemâ Frenk ayinine tâbi' olanlara tenbih ve nasîhat eyleyüp ba 'zllarl gelüp rücu' edüp Ermeni ayyinine girerler ve ba 'zıları bir vechile tembih olmayup 'biz Ermeni âyinine girmeyüz' deyü bu kullarına tâbi ' olmayup Sultânımdan mercûdur ki, Frenk âyininde olanlar kiliselerimize girmeyüp ve mürd oldukda papaslar evlerine varup kaldirmayup teftiş ve tefahhus edüp Ermeni âyinini icrâ eylemek bâbinda..."94

Aynı tarihlerde başka bir arzuhâlde, bu defa yeni bazı iddialarda bulunmuştu:

"Bu râhib kullara hâliyâ Ermeniyân üzerine İstanbul ve tevâbi'i patrikliği ihsân olınup mukaddemâ Frenk âyinine tâbi" olanlar kitaplarımızı Frenk âyinine tebdil edüp hâlâ Ermeni evladlarına ol minvâl üzere tâlim ederler. Sa'âdetlü Sultânımdan mercûdur ki bu kulları müstahak olan papaslardan biri papas kiliselerimizde biri ola içinde Ermeni evladlarını okudup taşrada bir kimesne Ermeni evladlarına tâlim ve dahl etmemek bâbında ... "95

Bu nevi iddia ve talepler karşısında Osmanlı Hükümeti'nin yaklaşımı neredeyse hiç değişmiyordu. "Mûcebince şer'ile hüküm buyuruldu" veya "derkenarı mûcebince yazıla" şeklindeki buyuruldu kayıtlarından, Patriğin iddialarının ne dereceye kadar ciddiye alındığını tahmin etmek güçtür. Lâkin konjonktürün Avedik'in aleyhine olduğu kesindir. Nitekim Edirne

\footnotetext{
${ }^{87}$ Ahmed Refik, Onikinci Asr-ı Hicride İstanbul Hayatı (1100-1200/1689-1785), İstanbul 1988, s. 22, 33, 35, 160-162.

${ }^{88}$ Katolik faaliyetleri hakkında genel bir değerlendirme için şu çalışmalara bakılabilir: Davut Kılıç, "Osmanlı Ermenilerine Yönelik Misyonerlik Faaliyetleri”, Tarihte Türkler ve Ermeniler, Cilt: 8, Türk Tarih Kurumu Yayınları, Ankara 2014, s. 87-126; Şenol Kantarc1, "Katolik Ermenilerin Anadolu'daki Faaliyetleri”, Tarihte Türkler ve Ermeniler, Cilt: 9, Ankara 2014, s. 63-79; Murat Bürkan Serbest, "Osmanlı'da Ermeni Katolik Kilisesi ve Toplumu", Hoşgörü Toplumunda Ermeniler, Cilt: 3, Kayseri 2007, s. 271-279; John Whooley, "The Armenian Catholic Church: A Study in History and Ecclesiology", Heythrop Journal, 45 (October 2004), s. 416-434.

${ }^{89}$ BOA, D.PSK, $2 / 48$.

${ }^{90}$ BOA, D.PSK, $2 / 58$ (9 Nisan 102).

${ }^{91}$ BOA, D.PSK, 2/60 (13 Nisan 1702).

${ }^{92}$ BOA, D.PSK, 2/82 (30 Haziran 1702).

${ }^{93}$ BOA, D.PSK, 2/88 (22 Temmuz 1702).

${ }^{94}$ BOA, D.PSK, $2 / 89$ (23 Temmuz 1702).

95 BOA, D.PSK, 2/100 (12 Ağustos 1702).
} 
Vakası'yla padişah ve iktidar değişikliği olunca, hâmisi Şeyhülislâm Feyzullah Efendi'yi kaybeden Patrik, Eylül 1703 'te görevden alınarak yerine Amasyalı I. Kalusd patrik olmuştur. ${ }^{96}$ Avedik'in ikinci defa patrik tayin edildiği 1705'e kadarki döneme ait arşiv belgelerinde, Frenklik meselesinin hiç gündeme gelmemiş olması dikkat çekicidir. Keza Patrik I. Avedik de, yaklaşık 15 ay süren ikinci görev süresi boyunca, ilk dönemine göre daha ihtiyatlı hareket ederek mücadeleyi bırakmış gibidir. Belki de vergi tahsili, kilise borçları ve şahsına yönelik suiistimal isnadı gibi “akçeli işler”le uğraşmaktan, Frenklerle mücadeleye fırsat bulamamış olmalıdır. Ama onun azlinden sonra 1706 'de patrik tayin edilen ve bir y1ldan az süre görevde kaldığ 1 anlaşılan Erzincanlı III. Mardiros, daha sonra sâbık Kudüs Patriği Matteos ile birlikte, "Frenk âyini üzere hareket ve ihtilâle" sebep oldukları gerekçesiyle, Padişah fermanıyla tutuklanarak kürek cezasına çarptırılmışlardır. ${ }^{97}$

Bitlisli IX. Hovhannes Golod'un 1715'te patrik olmasına kadar geçen y1llarda, resmî belgelerin bu husustaki sessizliğinden ötürü, cemaat arasında Katolikliğe eğilimin hangi mertebede olduğu sarih değildir. Yeni patriğin ilk aylarında Trabzon Marhasası Karabaş Apraham, "Frenk âyinine sülûk [ve] Ermeni tâifesini bir tarafdan Frenk dinine tâbi" eylediği" gerekçesiyle azledilmiştir. ${ }^{98}$ Patrik IX. Hovhannes, genel olarak cemaat içindeki dengeleri gözeten ve Katoliklere karşı sert tedbirler uygulamaktan ziyade 1lımlı yaklaşımı tercih eden bir kişi olarak bilinir. Ama yine de onun 26 yıllık uzun patriklik süresi boyunca da, zaman zaman Frenklik isnadıyla görevden almalar yaşanmıştır. ${ }^{99}$

\section{F. Eçmiyadzin Katogigosluğu İle Alakalı Meseleler}

Günümüzde Ermenistan'ın başkenti Erivan'ın $20 \mathrm{~km}$. batısında yer alan bir kasaba olan Eçmiyadzin (Osmanlı kaynaklarında çoğunlukla Üçkilise olarak geçer), geçmişte Ermeni Apostolik Kilisesi'nin merkezi olup, cemaat açısından önemi büyüktü. Bu bölge 18. yüzyıl başlarında İran hâkimiyetinde bulunduğu için, Osmanlı Devleti'nin ruhban tayininde müdahalesi söz konusu olmuyordu. Fakat Ermeni cemaatinin âyinlerinde kullandıkları kutsal yağ (balson, müron), daha önce verilen bir beratla Eçmiyadzin Kilisesi'nden gönderiliyordu. Ermeni cemaatinin 1712 'deki müşterek bir arzuhâlinde, bu hususta ellerinde olan beratlarının yenilenmesi talep edilmiş, 8 Kasım 1712 tarihinde buna onay verilmişti. ${ }^{100} \mathrm{Bu}$ şekilde kutsal yağ 1 dağıtmak için gelen râhiblerin, aynı zamanda Osmanlı tebaası Ermenilerden Eçmiyadzin için yardım toplamalarına da müsaade edilmiştir. İstanbul Patriği IX. Hovhannes’in Eylül 1725 tarihli arzuhâlinde yazıldığı gibi, Rumeli'de yardım için dolaşan Râhib Bogos'a bazı kimselerin muhalefeti ve ehl-i örfe şikayetleri gibi sıkıntılar, mahallî otoritelere yazılan emirlerle giderilmeye çalışılmıştır. ${ }^{101}$

Eçmiyadzin'i Osmanlı Devleti'nin ilgi alanına sokan asıl hadise, 1725'te Revan ve çevresinin İran'dan geri alınmasıdır. Bu tarihe kadar Eçmiyadzin Katogigosları İran tarafından atanırken, Osmanlı hâkimiyetine girmesinden sonra, neredeyse tüm işler doğrudan İstanbul Patriği IX. Hovhannes'in kontrolünde yürütülmeye başlandı. Son Katogigos İsidor öldüğünden, bu tarihte katogigosluk boş durumdaydı. Patrik Hovhannes'in elini çabuk tuttuğu görülür. Onun yönlendirmesiyle Ermeni ahali, cemaat tarafından yeni bir katogigos tayinine kadar başka yerlerden yapılacak müracaatlara itibar edilmemesi hususunda Divân-1 Hümâyun'a müracaata bulundular. ${ }^{102}$ Zaten kısa süre sonra Ekim 1725 tarihi itibariyle, Devlet-i Aliyye'de olan Ermeni ruhban tarafindan Râhib Garabed, Eçmiyadzin Katogigosu seçildi, buna hükümetin de bir itirazı olmadı. Ayrıca eskiden beri olageldiği üzere, Revan Hazinesine senelik 350 kuruş para ödemeleri

\footnotetext{
${ }^{96}$ BOA, D.PSK, $3 / 27$.

${ }^{97}$ BOA, D.PSK, $4 / 41$.

98 BOA, D.PSK, $5 / 58$ (5 Ağustos 1715). Râhib Apraham, daha sonra firar edecektir (BOA, $K K$, nr. 2542-1, s. 104).

${ }^{99}$ Urfa Marhasası Apraham, "Efrenc âyini üzere hareket" eyleyerek cemaat arasında ihtilâle sebep olduğu gerekçesiyle

3 Ağustos 1719 tarihinde azledilmiş ve yerine Râhib Bogos atanmıştır (BOA, $K K$, nr. 2542-1, s. 78).

100 BOA, D.PSK, 4/109.

${ }^{101}$ Patrik IX. Hovhannes'in arzı ve Rumeli'deki kadılara yazılan hüküm sureti: BOA, A.DVN, nr. 1138/61.

102 BOA, A.DVN, 1144/5.
} 
mukabelesinde, kendilerine muâfiyet beratı da verildi. ${ }^{103}$ Bundan sonra Eçmiyadzin Katogigosluğu, İstanbul Ermeni patriklerinin hükümetle münasebetlerinde önemli yere sahip olmaya devam edecektir. Katogigos seçimi, kutsal yağın dağıtılması, sadaka toplanması ve ziyaretler gibi hususlarda İstanbul Patriği IX. Hovhannes, hükümetle kurduğu sağlam münasebetin avantajını kullanarak aracı ve nüfuz kullanan dinî lider rolünü sürdürmüştür.

\section{Sonuç Yerine Bazı Tespitler}

Sadece bu muhtasar araştırmaya istinaden büyük genellemeler yapmak ve kesin neticeler çıkarmak güçtür. Ama yine de şu tespitler yapılabilir: Her şeyden önce gözden geçirilen resmî belgeler, 18. yüzyıl başlarında İstanbul Ermeni Patrikhanesi'nin, cemaatin hükümetle münasebetlerinde önemli bir mevkie sahip olduğuna işaret eder. Bu yönüyle patrikleri, sadece basit birer vergi tahsildarı (mültezim) olarak görmek mümkün değildir. Patriğin statü ve yetkisi, tartışmaya mahal bırakmayacak ölçüde geniş ve belirgindir. Patrik IX. Hovhannes'in göreve geldiği 1715 'e kadarki dönem, cemaat açısından oldukça sıkıntılı ve kaotiktir. Patriklik ve marhasalık görevleri için ruhban arasında çetin bir rekabet vardır. Ruhaniler arasındaki yozlaşma fark edilebilir boyuttadır. Cemaat bir yandan kendi iç sorunlarıyla uğraşırken, diğer yandan Katolik Latin Kilisesinin baskısı altındadır. Hükümetle münasebetlerde Kudüs ve Eçmiyadzin önemli yer tutmaktadır. Cemaatin iç işleyişine Osmanlı Hükümeti tarafından müdahale edildiğine dair açık işaretler yoktur. Fakat bazı devlet adamlarının, ruhanilerle kurdukları yakın münasebetlerin, İstanbul Patrikhanesi'ni ve cemaati etkilemiş olması muhtemeldir. Patrik IX. Hovhannes Golod'un, cemaati buhran döneminden çıkardığını söylemek mümkündür.

\section{KAYNAKÇA}

\section{Başbakanlık Osmanlı Arşivi (BOA)}

Kamil Kepeci $(K K)$, nr. 2542-1, 2542-2, 2542-8.

Mühimme Defteri (MD), nr. 111.

İbnülemin Dahiliye, nr. 1241, 1811, 1863, 2082, 2462, 2955.

Cevdet Adliye, nr. 51, 77, 1023, 3034, 3351, 3489, 4780.

Bâb-1 Defteri Piskoposluk Kalemi (D.PSK), Dosya nr: 1, 2, 3, 4, 5, 6, 7, 8, 9, 11, 12.

Bâb-1 Asafi Divan (Beylikçi) Kalemi (A.DVN), Dosya nr: 812, 936, 1138, 1144, 1141.

\section{Kitap ve Makaleler}

ADIYEKE, Nuri, "Islahat Fermanı Öncesinde Osmanlı İmparatorluğu'nda Millet Sistemi ve Gayrimüslimlerin Yaşantılarına Dair", Osmanl,, Cilt: 4, Editör: Güler Eren, Yeni Türkiye Yayınları, Ankara 1999, s. 255-261.

AHMED REFIK, Onikinci Asr-ı Hicride İstanbul Hayatı (1100-1200/1689-1785), İstanbul 1988.

BOUMOUTIAN, George A., Ermeni Tarihi, Ermeni Halklarının Tarihine Kısa Bakış, Çeviri: Ender Abadoğlu - Ohannes K1lıçdağı, Aras Yayıncılık, İstanbul 1011.

BOZDOĞAN, Günay Göksu-Füsun Üstel-Karin Karakaş1-Ferhat Kentel, Türkiye'de Ermeniler, Cemaat-Birey-Yurttaş, İstanbul Bilgi Üniversitesi Yayınları, İstanbul 2009.

BRAUDE, Benjamin, "Foundation Myths of the Millet System", Christians and Jews in the Ottoman Empire, the Functioning of a Plural Society, ed. B. Braude \& B. Lewis, C. I, New York 1982, s. 69-88.

${ }^{103}$ BOA, A.DVN, 1141/51. 
BRAUDE, Benjamin, "Millet Sisteminin İlginç Tarihi”, Osmanll, Cilt: 4, Editör: Güler Eren, Ankara 1999, s. 245-254.

ÇARKÇIYAN, Rahip G., Türk Devleti Hizmetinde Ermeniler, Kesit Yayınları, İstanbul 2006.

ÇELEBİZÂDE İSMÂİL ÂSIM EFENDİ, Târîh-i Çelebizâde, Hazırlayan: Abdülkadir Özcan, Ahmet Zeki İzgöer, Yunus Uğur, Baki Çakır, Klasik Yayınları, İstanbul 2013.

ÇELIK, Recep, “Osmanlı Bürokrasisinde Görev Yapan Ermeniler”, Hoşgörü Toplumunda Ermeniler, Cilt: 4, Kayseri 2007, s. 27-53.

DAMATYAN, Krikor, "Patrik IX. Hovhannes Döneminde Yayın Faaliyetinin Gelişimi”, Hoşgörü Toplumunda Ermeniler, Cilt: 2, Kayseri 2007, s.467-481.

DEDEYAN, Gerard, Ermeni Halkının Tarihi, Derleyen: Gerard Dedeyan, Fransızca'dan Çeviren: Şule Çiltaş, Ayrıntı Yayınları, İstanbul 1015.

ERCAN, Yavuz, "Osmanlı Devleti'nde Müslüman Olmayan Topluluklar (Millet Sistemi)", Osmanl, Cilt: 4, Editör: Güler Eren, Ankara 1999, s. 197-207.

GÜLER, İbrahim, "XVIII. Yüzyıl Osmanlı Toplumunda Ermeniler: Gözlemler ve Düşünceler”, Hoşgörü Toplumunda Ermeniler, Cilt: 2, Kayseri 2007, s. 333-361.

KANTARCI, Şenol, "Katolik Ermenilerin Anadolu'daki Faaliyetleri”, Tarihte Türkler ve Ermeniler, Cilt: 9, Türk Tarih Kurumu Yayınları, Ankara 2014, s. 63-79.

KENANOĞLU, M. Macit, Osmanlı Millet Sistemi, Mit ve Gerçek, Klasik Yayınları, İstanbul 2004.

KILIÇ, Davut, Tarihten Günümüze İstanbul Ermeni Patrikhanesi, Atatürk Kültür Dil ve Tarih Yüksek Kurumu Yayınları, Ankara 2008.

KILIÇ, Davut, "Osmanlı Ermenilerine Yönelik Misyonerlik Faaliyetleri”, Tarihte Türkler ve Ermeniler, Cilt: 8, Türk Tarih Kurumu Yayınları, Ankara 2014, s. 87-126.

KÖSE, Ensar, "Bir Hayalin Peşinde Yüz Yıl: Kudüs ve İstanbul Ermeni Patrikliğini Birleştirme Çabaları (1650-1750)", İstanbul Üniversitesi Edebiyat Fakültesi Tarih Dergisi, Say1: 63 (2016/1), İstanbul 2016, s. 41-88.

KURAT, Yuluğ Tekin, “Çok Milletli Bir Ulus Olarak Osmanlı İmparatorluğu”, Osmanlı, Cilt: 4, Editör: Güler Eren, Ankara 1999, s. 217-222.

KÜÇÜK, Cevdet, “Osmanlı Devleti'nde Millet Sistemi”, Osmanl, Cilt: 4, Editör: Güler Eren, Ankara 1999, s. 208-216.

SAĞIRLI, Abdurrahman, "Ermenileri Katolikleştirme Çalışmaları ve Sonuçları Hakkında 1778 Y1lında Hazırlanan Bir Rapor", Hoşgörü Toplumunda Ermeniler, Cilt: 1, Kayseri 2007, s. 146-159.

SERBEST, Murat Bürkan, "Osmanlı'da Ermeni Katolik Kilisesi ve Toplumu”, Hoşgörü Toplumunda Ermeniler, Cilt: 3, Kayseri 2007, s. 271-279.

SEYFELİ, Canan, İstanbul Ermeni Patrikliği, Aziz Andaç Yayınları, Ankara 2005.

ŞAHIN, Gürsoy, Osmanlı Devleti'nde Katolik Ermeniler Sivaslı Mihitar ve Mihitaristler (16761749), IQ Kültür Sanat Yayıncılık, İstanbul 2008.

WHOOLEY, John, "The Armenian Catholic Church: A Study in History and Ecclesiology”, Heythrop Journal, 45 (October 2004), s. 416-434. 


\section{EK BELGE VE GÖRÜNTÜLER}

Belge 1: İstanbul Ermeni Patriği Mıkhitar'ın arzuhâli, üzerinde derkenar kayıtları ve buyuruldu; 10 Mart 1700; (BOA, D.PSK, 1/186).

Devletlü ve sa 'âdetlü Sultânım hazretlerinin hâkipâ-yl şerîflerine yüzüm ve gözüm sürdükden sonra bâ 'is-i arz-ı ubûdiyyet budur ki,

Medine-i Ruscuk'da sâkin Ermeniyân tâifesinin üzerlerine papas olan Melkisetek veledi Haçadur nâm zimmî kendü hâlinde olmayup dâima telbîsat ve ehl-i fesâd ve sû-i hâl ile mevsuf olmağla hakkından geline deyü hâkipâya arz gönderüp ve bu kullarına havâle buyurulmağla mezbûr papas her vechile şakī ve ehl-i fesâd olduğundan mâ 'adâ yedimde olan berat-ı âlî-şânıma itâ'at etmeyüp mîrîye noksan olup ve medîne-i mezbûrde sâkin olan Ermeniyân tâifesi mezbûr papasdan râzı ve hoşnud olmayup âyinimize muhâlif işler itmekle merhametlü Sultânımdan mercûdur ki mezbûr Melkisetek veledi Haçadur nâm papas Ruscuk'da oturmayup Malkara mezbûrun kendü vilâyeti olmağla Malkara nâm mevzi'e nefy olunup Ermeniyânın hayır du'âsına mazhar olasız diyü hâkipâya arzu u i'lâm olundı. Bâki emr [ü] ferman devletlü merhametlü Sultânımındır. Bende Mikhitar, Patrik-i İstanbul.

- Arzı mûcebince hüküm buyuruldu.

Belge 2: İstanbul Ermeni Patriği Mıkhitar'ın arzı üzerine, Magosa Kalesi Dizdarı'na hitaben yazılan hüküm; Temmuz 1700; (BOA, MD, nr. 111, s. 340, hkm. 1176).

Magosa kal 'ası dizdârına hüküm ki,

Hâlâ Ermeni Patriği olan Mikhitar nâm râhib südde-i sa 'âdetime arz-ı hâl gönderüp sâbı kā Ermeni Patriği olan Sahak nâm râhib bundan akdem ibâdullâha zulm ü ta 'addî ve fesâd ü şenâ 'atı hasebiyle sâdir olan emr-i șerîf mûcebince Kıbris cezîresinde vâki 'Magosa kal 'asina kal 'a-bend olunmuş iken bir tarik ile halâs ve hâlâ Âsitâne-i Sa'âdetime gelüp yine kendü hâlinde olmayup patrikliği umuruna karışup ve patrik olsam gerek deyü Ermeni tâifesinden celb-i mâl ve beynlerine ihtilâl verüp ta' 'addî ve fesâd üzere olduğun bildirüp ta 'yin olınan çavuş mübâşeretiyle mesfur yine Magosa kal 'asında kal 'a-bend olunmak bâbında hüküm recâ itmeğin ahkâmı kaydına mürâca'at olındukda minvâl-ı meşrûhü üzere emr-i şerîf verildiği mastur ve mukayyed bulunmağın vech-i meşrûh üzere amel olunmak emrüm verilmişdir.

Belge 3: İstanbul Ermeni Patriği Yeprem'in arzuhâli, derkenar kaydı ve buyuruldu; 13 Şubat 1702; (BOA, D.PSK, 2/44).

Devletlü ve sa âdetlü Sultânım hazretleri săg olsun.

Bi’l-fi 'l patrikliğime dâhil Sivas marhasası olan Sahak nâm marhasa Sivas ve tevâbi 'i Venk$i$ Kebir Surp Nişan Manastırı'nın eşyâların kendü hevâ ü hevesine harc u sarf edüp ve manastır$\iota$ mezbûrı küllî duyuna koyup medyun olmağla mahal ü müstahak olan Hovhannes nâm râhibi marhasa ve îrad ve masrafina Apraham nâm zimmî nâzır nasb edüp ve âdet-i pişkeşi teslîm-i hazîne edüp yedine berat-ı âlî-şân sadaka ve ihsân olunmak bâbında emr [ü] ferman devletlü ve sa âdetlü Sultânımındır. Bende Yeprem Râhib, Patrik-i İstanbul.

- Pişkeşi alınup beratı verile [buyuruldu].

Belge 4: İstanbul Ermeni Patriği Avedik'in arzuhâli, derkenar kaydı ve buyuruldu; 2 Nisan 1702; (BOA, D.PSK, 2/53).

Devletül ve sa âdetlü Sultânım hazretleri săg olsun.

Bi'l-fi'l patrikliğime dâhil Erzincan kazâsına tâbi' Kayuse nâm karyede vâki 'Surp Hagop nâm manastırın vakıf olan tarlalarına ve çayırlarına ve bă̆ ve bağçe ve değirmenlerine ve çiftliklerine ve meralarına yedimizde olan berat-ı âlî-şânda tasrih olunduğı üzere ve yedimde olan vakfiyye-i ma 'mul-baha ve hüccet-i şer 'iyye ve fetevâ-yl şerîfe mûcebince müdâhale oluna gelmiş değil iken ve kilise-i mezbur toprağında cârî olan su kendü toprağın să̆i ide-gelüp ba'dehu Seluke nâm karyeye icrâ oluna-gelüp ve kiliseye vakıf ve müte 'allik olan eşyâlarına Seluke nâm karye müdâhale edüp küllî gadr mercûdur ki yedimizde olan berat-ı âlî-şân vakfiyye-i ma 'mûliyye ve cihet-i şer 'iyye ve fetevâ-yl şerîfe ve sûret-i defter mûcebince kilise-i mezbûrun toprăğnda 
olan sögüd ve topră̆ında saği etdirdüp kiliseye müte 'allik olan eşyâlarına Seluke nâm karyeyi ve âharı müdâhale etdirilmemek bâbında Erzincan kādısına hitâben fermân-ı şerîf recâ ve niyaz olunur. Bende Avedik Râhib, Patrik-i İstanbul.

- Derkenarı mûcebince yazıl [buyuruldu].

Belge 5: İstanbul Ermeni Patriği Nerses'in arzuhâli, derkenar ve buyuruldu; 23 Mayıs 1704; (BOA, D.PSK, 3/47).

Devletlü ve sa 'âdetlü Sultânım hazretleri săg olsun.

Bi'l-fi'l patrikliğime dâhil Kars ve Çıldır sancaklarında olan Ermeni tâifesi üzerlerine ve Şuragel nâhiyesinde vâki ' Hasvanik nâm manastırında marhasa olan Daniel nâm râhibin yedinde olan beratı tecdîd olunmak bâbında inâyet recâ itmekle âdet-i pişkeşi teslîm-i hazîne edüp yedine müceddeden berat-ı âlî-şân sadaka ve ihsan olunmak bâbında emr [ü] ferman Sultânım hazretlerinindir. Bende Nerses Râhib, Patrik-i İstanbul.

- Kānun üzere yazıla [buyuruldu].

Belge 6: İstanbul Ermeni Patriği Mardiros'un arzuhâli, derkenar kaydı ve buyuruldu; 25 Nisan 1706; (BOA, D.PSK, 3/150).

Devletlü [ve] sa 'âdetlü Sultânım hazretleri săg olsun.

Bu kullart Istanbul'da ve Anadolu'da ve Rumeli'nde sâkin Ermeniyân Patriği olup patrikliğime dâhil Istanbul'da ve Adana'da ve âhar yerlerde sâkin olan Ermeni tâifesi birbirlerine tezvic eylemek istediklerinde âyin-i bâtılımız üzere benim ma'rifetim ile yâhud patrikliğime dâhil yerlerde marhasa olanlar ma 'rifetiyle yâhud marhasaların papasları ma 'rifeti izni ile olunurlar iken ve yedime verilen berat-ı âli-şânda dahi tasrih olunup dahl olunmak lüzum gelmez iken ve yine bir Ermeni mürd oldukda marhasalar yâhud papasları üzerine İncil okuyup kaldıra-gelmişler iken ba'zı Ermeni tâifesi âyinimize muhâlif ve berat-ı âlî-şâna mugāyir âhara nikâh etdirdüklerinden gayri hafiyyeten kādılara ve nâiblere dört beş kerre nikâh etdirüp mîrîye ve bu kullarına gadr devletlü Sultânımdan mercûdur ki bu makūle Ermeni tâifesinin nikâhı benim ma 'rifetimle yâhud marhasalar yâhud papaslar ma 'rifeti izniyle olup mücerred celb-i mâl içün kādılar ve nâibler [ve] voyvodalar ve subaşıları ve yasakcılar ve kolcılar ve zî-kudret kimesneler ve ehl-i örf tâifesi karışmamak üzere bundan önce verilen fermanımız tecdîden ve mûcebince mâliyeden ferman ihsan olunmak bâbında emr [ü] ferman Sultânımındır. Bende Mardiros, Patrik-i Ermeniyân.

- Derkenarı mûcebince mâliyeden şürutıyla hüküm buyuruldu.

Belge 7: İstanbul Ermeni Patriği Mikael'in arzuhâli, derkenar ve buyuruldu; 11 Eylül 1706; (BOA, D.PSK, 3/177).

Devletlü ve merhametlü Sultânım hazretleri sağ olsun.

Erzurum sancağında Asdvadzadzin Manastırı'nın marhasası mürd olup mezbur manastır mahlûl olmağın merhametlü Sultânımdan mercûdur ki zamân-ı devletlerinde bu kullarına her vechile mahal ü müstahak olup pişkeşi elinde Hazîne-i Âmire ye teslim olunup İstepannos Râhibe sadaka edüp yedine berat-l âli-şân verilmesi bâbında bâki emr ü ferman merhametlü Sultânımındır. Bende Mikael, Patrik-i İstanbul.

- Mûcebince tevcih olunmak buyuruldu. 2 C sene [1]118.

Belge 8: İstanbul Ermeni Patriği Sahak'ın arzuhâli üzerine, marhasa tayin hakkında Karahisarışarki Kadısı'na yazılan hüküm; 14 Eylül 1710; (BOA, KK, nr. 2542-2, s. 50).

Karahisarışarki kādısına hüküm ki,

Istanbul ve tevâbi'i Ermeni patriği olan Sahak nâm râhib Dîvân-ı Hümâyûn'uma arz gönderüp Karahisar-ı Şarkî kazâsına tâbi' Temze nâm karyede vâki' Tamura manastırı marhasası olan Zakarya nâm râhib manastırlarını harâbe koyup ref'i lâzım gelmekle yerine mahal ü müstahak olan Garabed nâm râhibe zabt ve âyinleri üzere vâki 'olan cüz'î ve küllî her marhasalık rüsûmı ahz u kabz etdirilüp hilâf-ı emr-i şerîf ref" olunan Zakarya râhibi ve âharı müdâhale etdirilmemek bâbında emr-i şerîfim recâ eylediği ecilden Hazîne-i Âmiremde mahfuz 
olan Mukāta'at Defterlerine nazar olundukda manastır-ı mezbûrın marhasalı̆̆ Zakarya nâm râhibe zabt etdirilmek üzere emr-i şerîf verildiği derkenâr olunmağla mesfûra derkenarı mûcebince zabtı içün hüküm deyü fermân-ı âlı̂ sâdır olmağın bin yüz yiğirmi iki Recebinin yiğirminci günü emr-i şerîf verilmişdir. Fî 20 Receb sene [1] 122.

Belge 9: İstanbul ve Kudüs Ermeni Patriği Hovhannes'in arzuhâli, derkenar ve buyuruldu; 27 Mart 1716; (BOA, D.PSK, 5/88).

Devletlü ve sa'âdetlü Sultânim hazretleri săg olsun.

Bu kulları hâlâ İstanbul ve Kudüs-i Şerîf Ermeniyân Patriği olup vilâyet-i Anadolu ve Rumeli câniblerinde sâkin Ermeni tâifesinden mu'tad-ı kadim ve âyinimiz üzere Kudüs-i Şerîf manastırları ve fukarâsı içün tasadduk ve tezvîrat akçası içün Kudüs-i Şerîf Patriği tarafindan irsâl eylediği vekillere ahz u kabz etdirilüp âhardan müdâhale olunmayup ve berat-ı âlî-şân şürûtı mûcebince ba'zı mahvf ve muhatara olan mahâllerden ahsen vechile geçmek içün tebdîl-i câme ve kisve eylediklerinde ehl-i örf tâifesi taraflarından ta 'addî olunmaya deyü fermân-ı âlî verilegelmekle devletlü Sultânımdan mercûdur ki mahâllinden derkenâr ve mûcebince vech-i meşrûh üzere tasaddukāt ve tezvirat içün vekillerine bir vechile rencîde ve ta 'addî olunmaya deyü hükm$i$ şerîf recâ olunur. Bâki emr [ü] ferman devletlü Sultânım hazretlerinindir. Bende Hovhannes Râhib, Patrik-i Ermeniyân-ı İstanbul ve Kudüs-i Şerif.

- Derkenarı mûcebince mahâllinden kayd ile yazıla [buyuruldu].

Belge 10: İstanbul Ermeni Patriği Hovhannes'in arzuhâli, hüküm sureti ve buyuruldu; 13 Şubat 1723; (BOA, D.PSK, 7/129).

Devletlü [ve] sa'âdetlü Sultânım hazretleri sağ olsun.

Bu kulları Ístanbul ve tevâbi 'i Ermeni Patriği olup bundan akdem kendü hâlinde olmayup ihtilâl-i azîmesi zuhûr eden Mikael nâm râhib İstanbul'da ahz ve sâdır olan fermân-ı âlî mûcebince eyâlet-i Van'da vâki 'Ahtamar nâm manastırımız olduğı cezîreye nefy ve cezîre-bend ve manastır-ı mezkûrde ikāmet olunmak üzere irsâl olunmuşdı. Millet-i Ermeniyân beyninde henüz ihtilâli def' olunmuşiken şimdi ba 'zı kimesne mesfûrun ıtlâkına sa 'y ve devr-i ebvâb edüp ihtilâli tecdîd murâd etmeleriyle mercûdur ki mesfûrun itlâkına müsâ 'ade olunmayup bir tarikle buyurulup kaleme vardukda dahi tekrar inâyetlü Sultânım hazretlerine istizan olınup iki sah'lı ferman olunmadıkça emr-i şerîf tahrîr olunmamak bâbında Dîvan Kaleminde kaydına şerh verilmek içün emr ü ferman devletlü Sultânım hazretlerinindir. Bende Hovhannes Râhib, Patrik$i$ Ermeniyân-ı İstanbul ve tevâbi 'i.

- Mûcebince kaydı mahalline kayd ve şerh verilmek buyuruldu. 7 Ca sene [1]135. 
Belge Görüntüsü 1: İstanbul Ermeni Patriği Mıkhitar'ın, cemaat mensuplarının nikâh sorunları hakkında arzuhâli; 11 Mart 1700; (BOA, İbnülemin Dahiliye, nr. 1241).

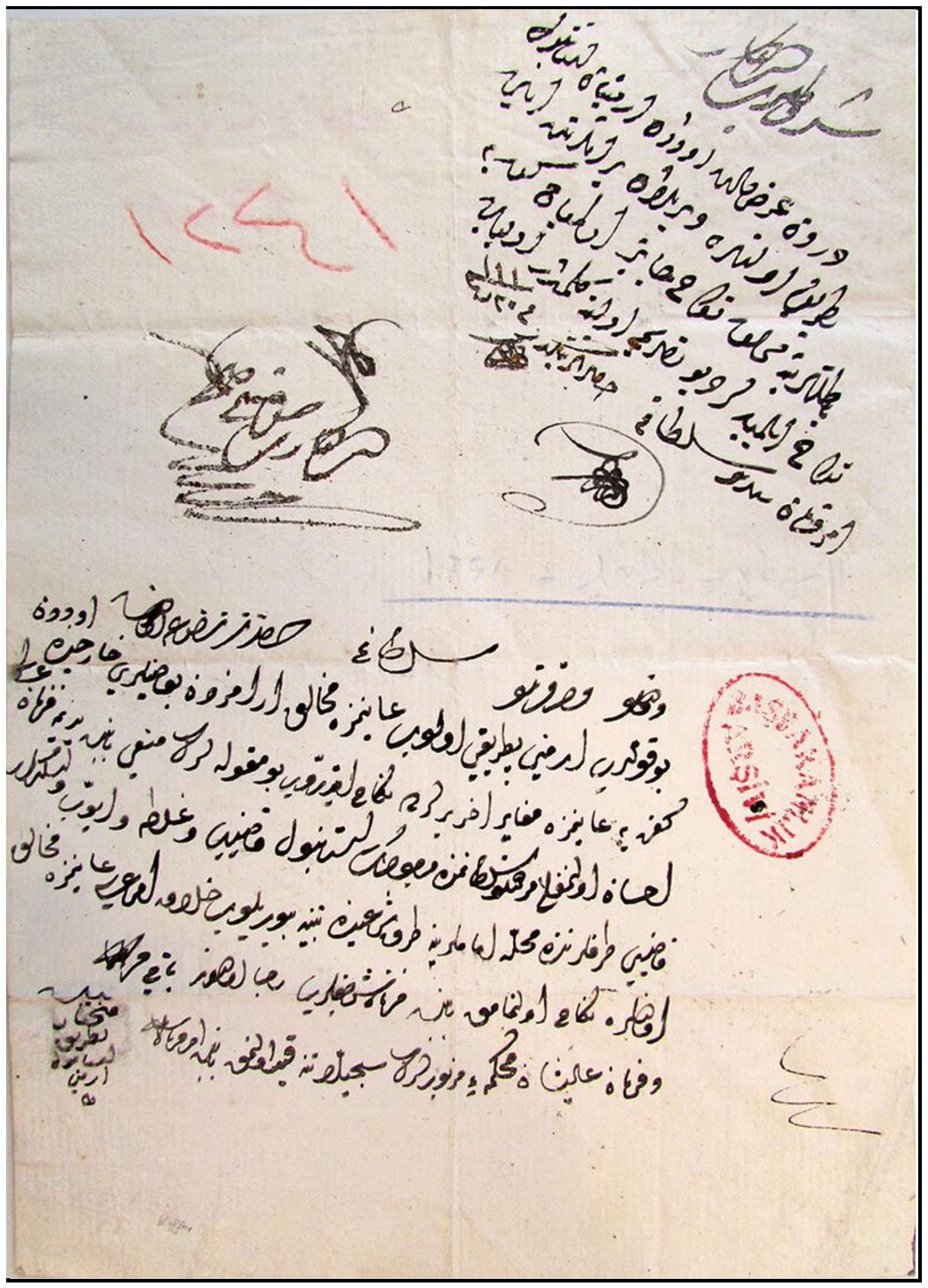


Belge Görüntüsü 2: İstanbul Ermeni Patriği Kalust'un, Ankara'ya marhasa tayini hakkında arzuhâli; 19 Ekim 1703; (BOA, İbnülemin Dahiliye, nr. 1903).

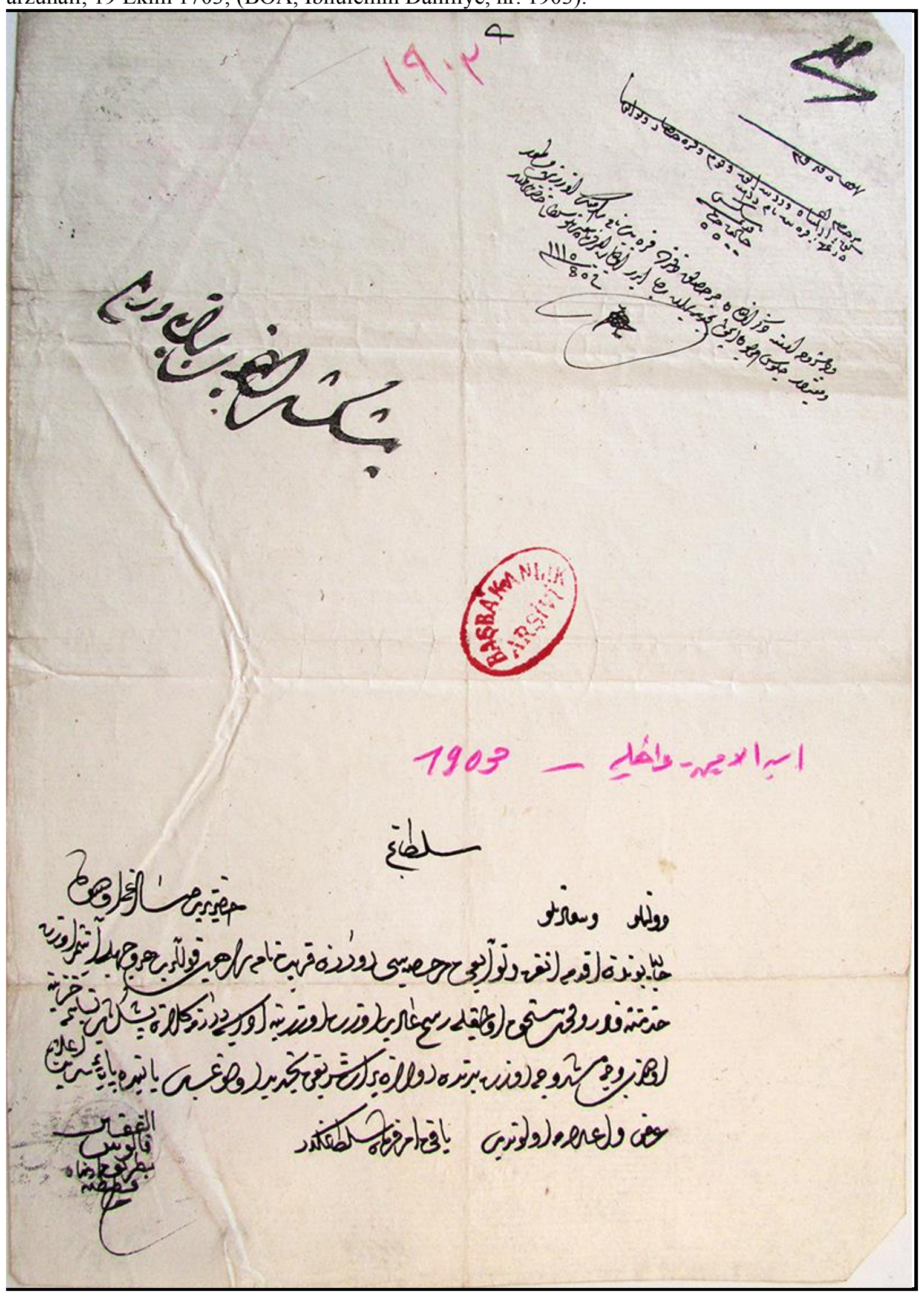


Belge Görüntüsü 3: İstanbul Ermeni Patriği Hovhannes'in, makamına tayini hakkında berat-1 şerîf verilmesi talebini havî arzuhâli, derkenar kaydı, telhis ve buyuruldu; 18 Nisan 1714; (BOA, D.PSK, 5/1).

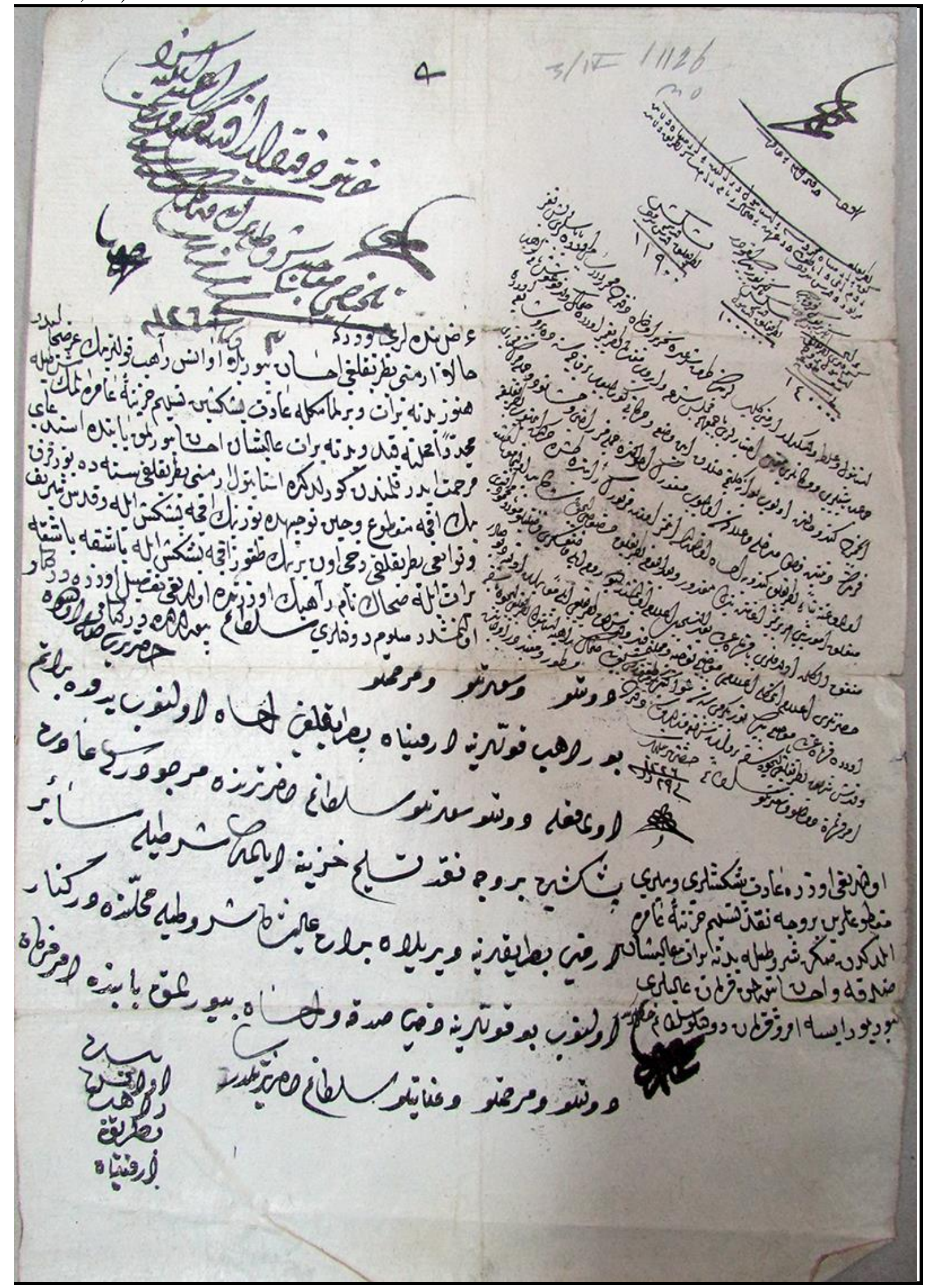


Belge Görüntüsü 4: İstanbul ve Kudüs Ermeni Patriği Hovhannes'in, Trabzon'da Frenk âyinine tevessül eden Karabaş Apraham hakkında arzuhâli, derkenar ve buyuruldu; 5 Ağustos 1715; (BOA, D.PSK, 5/58).

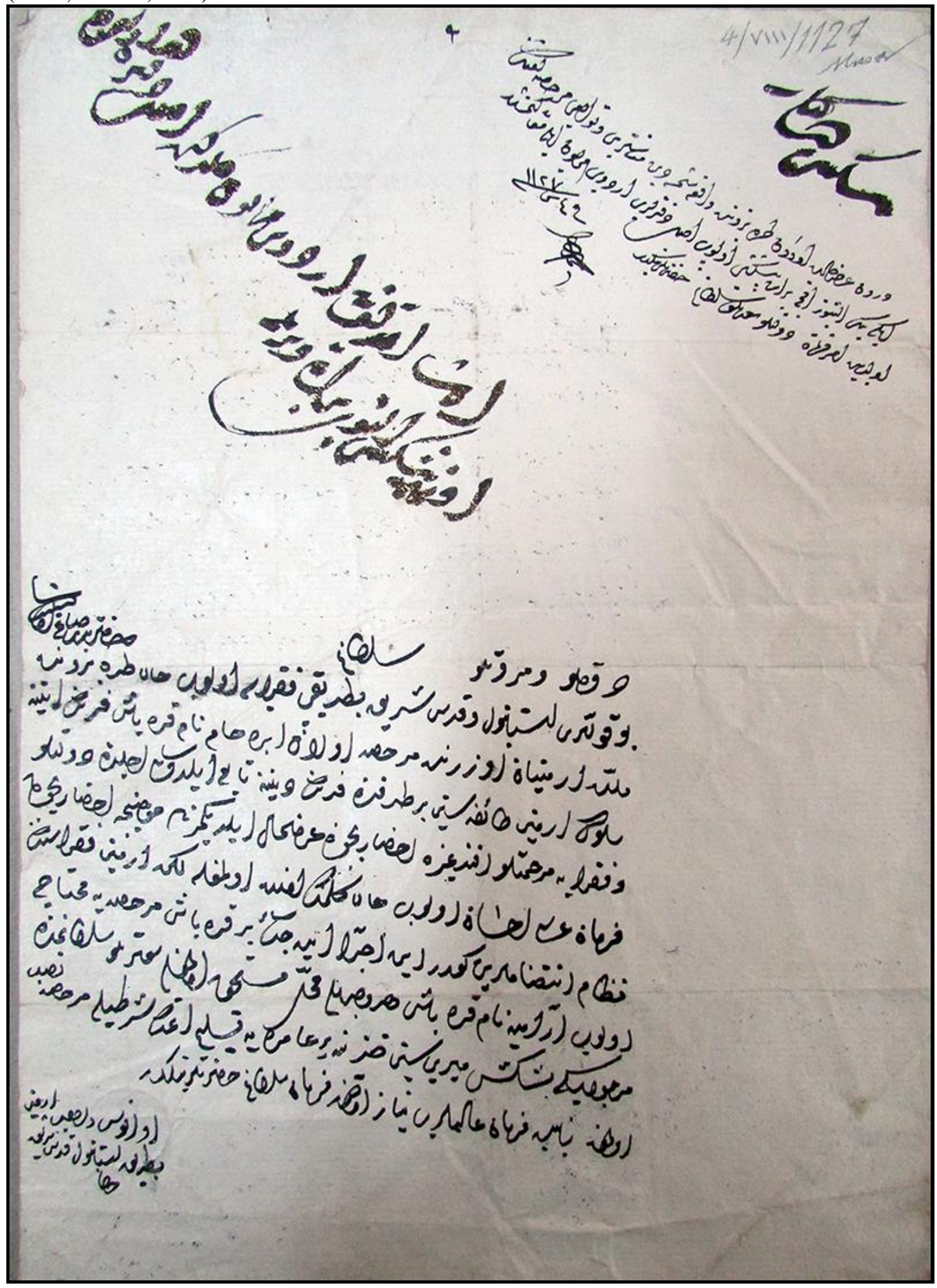


Belge Görüntüsü 5: İstanbul Ermeni Patriği Hovhannes’in, ölümünden kisa süre önce Erzincan'daki Ermeni cemaatinin sorunlarına dair sunduğu arzuhâl, derkenar kaydı, telhis ve buyuruldu; 7 Şubat 1741; (BOA, D.PSK, 12/28).

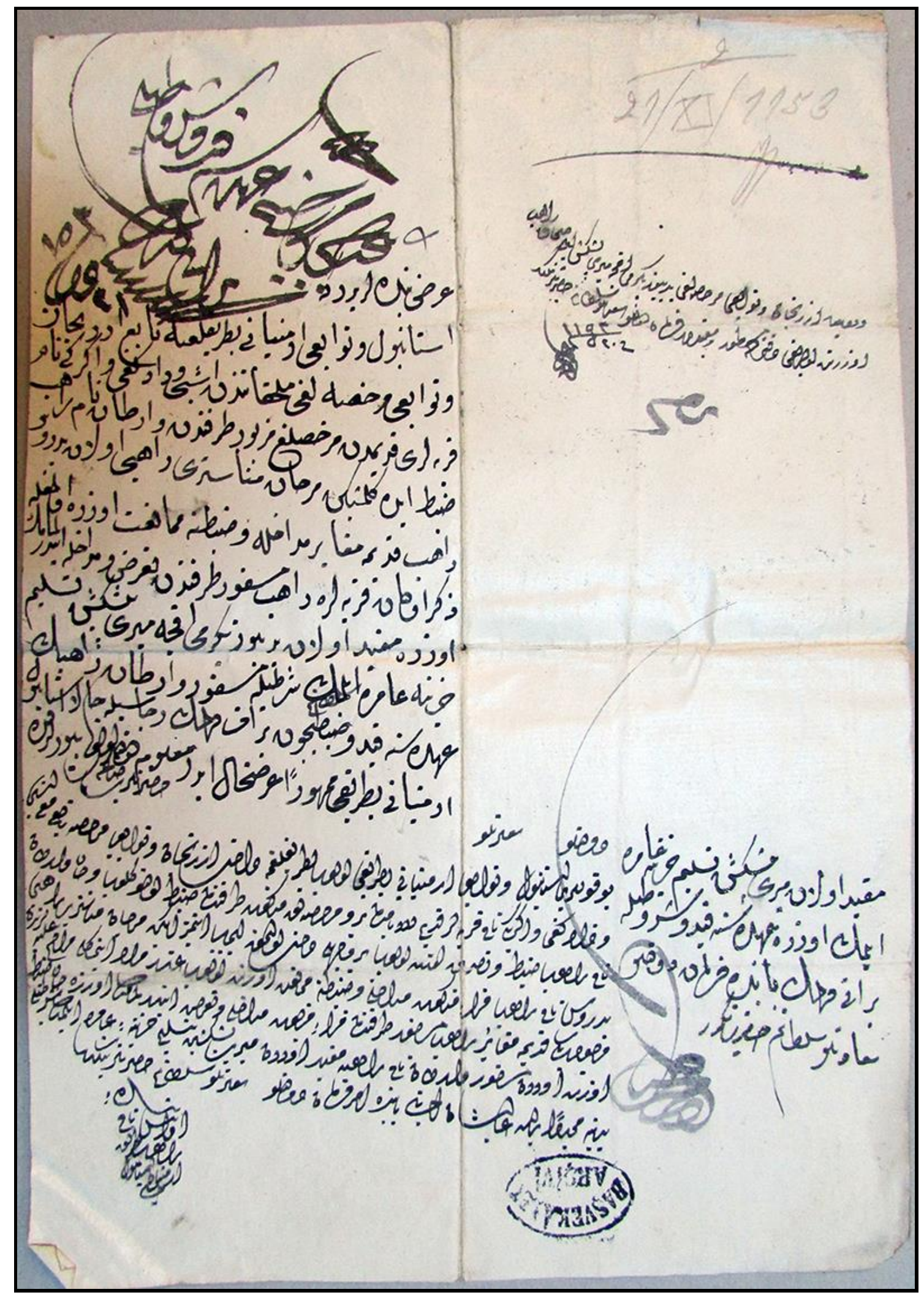

